\title{
THE RELATIONSHIP BETWEEN DIET, NUTRITION AND DENTAL HEALTH: AN OVERVIEW AND UPDATE FOR THE 90s
}

\author{
PAULA J. MOYNIHAN
}

The Dental School, University of Newcastle, Framlington Place, Newcastle upon Tyne NE2 4BW

\section{CONTENTS}

INTRODUCTION

THE EFFECTS OF DIET AND NUTRITIONAL STATUS ON DENTAL HEALTH.

THE RELATIONSHIP BETWEEN DIET AND NUTRITIONAL STATUS, AND PERIODONTAL DISEASE

FACTORS IN THE DIET WHICH PROTECT AGAINST DENTAL CARIES

Fluoride.

Other protective factors.

DENTAL CARIES - THE ROLE OF DIETARY SUGARS . . . . . . . . 201

Epidemiological surveys. . . . . . . . . . . . . . . . . . . . . . $\quad$. 202

Animal studies .

Enamel slab and plaque pH studies . . . . . . . . . . . . . 205

Frequency and amount of sugars intake . . . . . . . . . . . . . . . 506

DENTAL CARIES - THE ROLE OF DIETARY STARCH . . . . . . . . 207

CORN STARCH SWEETENERS AND DENTAL HEALTH. . . . . . . . 209

ORAL RETENTION OF FOOD AND CARIES RISK . . . . . . . . . . 210

NON-SUGAR SWEETENERS . . . . . . . . . . . . . . . 211

MALNUTRITION AND DENTAL CARIES . . . . . . . . . . . . . 211

DIETARY CAUSES OF DENTAL EROSION . . . . . . . . . . . . 212

THE RELATIONSHIP BETWEEN TOOTH LOSS, DIET AND
NUTRITIONAL STATUS

THE INFLUENCE OF TOOTH LOSS ON THE DIGESTION OF FOODS . . . 213

THE INFLUENCE OF TOOTH LOSS ON THE CHOICE OF FOODS . . . . . 213

THE INFLUENCE OF TOOTH LOSS ON THE INTAKE OF NUTRIENTS AND NUTRITIONAL STATUS . . . . . . . . . . . . . . . 214

THE BENEFITS OF DENTAL PROSTHESES ON CHEWING ABILITY, FOOD CHOICE AND NUTRITIONAL STATUS . . . . . . . . . . . . . . . . 214 CONCLUSIONS . . . . . . . . . . . . . . . . . . . 215

REFERENCES . . . . . . . . . . . . . . . . . . . 215 


\section{INTRODUCTION}

Dental diseases impose considerable financial and social burdens. In the United Kingdom the treatment of dental diseases costs more than twice the cost of treating heart disease, over 900 million pounds per annum, and British adults on average suffer three days of dental pain a year. Dental caries, periodontal disease, dental erosion and edentulousness are all prevalent in developed countries.

The 1993 Children's Dental Health Survey (O'Brien, 1994) has shown that between 1983 and 1993 there have been considerable reductions in the number of decayed, missing and filled permanent teeth (DMFT). In 1983 the DMFT for 15-year-old children surveyed was 5.9 and only $7 \%$ were caries free, whereas in 1993 the proportion who were caries free had risen to $37 \%$ and the average DMFT was $2 \cdot 5$. However, there has been little improvement in the proportion of children with actively decayed primary teeth over the past decade. In 1983 the average number of decayed filled and missing teeth for the 5-year-old age group was $2 \cdot 1$, and $52 \%$ were caries free. In $199355 \%$ of 5-year-old children were caries free and the average for decayed, missing and filled teeth was 2.0. The 1993 Children's Dental Health Survey also reported that, by age $15,60 \%$ of English children and $85 \%$ of children from Northern Ireland still had some decayed permanent teeth. If the downward trend in dental caries is to be maintained, even improved, it is essential that there is continued emphasis on maintaining oral health through dietary and other means.

There have been significant improvements in adult tooth retention over the years and now there is a real expectation that people will retain their teeth for life (Department of Health, 1994a). The elderly are now becoming a group who are at risk of dental caries, due to tooth root exposure and reduced salivary flow associated with ageing.

The purpose of this review is to provide an overall insight and update on research into the relationship between diet and dental health.

\section{THE EFFECTS OF DIET AND NUTRITIONAL STATUS ON DENTAL HEALTH}

It is now desirable to retain teeth for life, not only because of the dietary restrictions of tooth loss but also for aesthetic purposes and general well being. The two main causes of tooth loss are dental caries and periodontal disease (periodontitis); the aetiology of both is influenced by food and nutrients in the diet.

\section{THE RELATIONSHIP BETWEEN DIET AND NUTRITIONAL STATUS, AND PERIODONTAL DISEASE}

Periodontal disease is one of the most common diseases in the UK and is likely to be the main cause of tooth loss in the world. Periodontal disease arises as a result of an interaction between plaque and its products and the host's immunological and inflammatory response. Although the presence of dental plaque is undoubtedly the principal aetiological factor, for the same amount of plaque there appears to be a wide variation in individual response and therefore other factors, such as nutritional status, are also likely to be involved.

Periodontal disease first manifests as gingivitis - inflammation of the gums without loss of attachment of teeth. In chronic gingivitis there is loosening of the epithelial/enamel junction and the development of a gingival pocket. Periodontitis involves inflammation of the dental supporting tissues (periodontal ligament and alveolar bone). It results from apical progression of gingival inflammation to form a periodontal pocket and eventual loss 
of attachment of the tooth. An informative description of the development of gingivitis and periodontitis is given by Lindhe (1989).

The relationship between diet and periodontal disease reaches back to the seventeenth century when Lind, a dental officer serving in the British Navy, discovered that supplementation of the diets of sailors with citrus fruit both prevented and cured the oral symptoms of scurvy. Diet and nutritional status may affect periodontal health in several ways, namely: plaque amount and composition, epithelial integrity, collagen formation and repair, bone formation and repair, the immune response and protection against free radical damage.

The composition of the diet can affect the amount and consistency of plaque. Carlsson \& Egelberg (1965) found that supplementing the diet with sucrose increased plaque volume and that this was not observed when the diet was supplemented with glucose. RateitschakPluss \& Guggenheim (1982) found that supplementing the diet with sucrose sweets resulted in higher plaque scores than when the diet was supplemented with sweets containing polyols. In addition to the type of carbohydrate in the diet the amount is also important. In studies of human experimental gingivitis, higher bleeding scores have been shown to occur on high compared to low carbohydrate diets and frequent sugar intake increased gingival inflammation (Sidi \& Ashley, 1984). Similar findings have been reported by other investigators (Jalil et al. 1983; Gaengler et al. 1986). However, the maximum reduction in sugar in the diet within the limits of practicality is not capable of preventing gingivitis (Gaengler et al. 1986).

There have been claims that the physical character of the diet affects the gingivae and that fibrous foods protect against gingivitis. In an early review, O'Rourke (1947) concluded that physical character of the diet significantly influenced periodontal health by exercising the gums, keratinization of the gingivae and cleaning the teeth. There seems, however, to be very little evidence, if any at all, to support these conclusions. Fibrous foods remove plaque only from exposed surfaces and the area around the gingival margin seems little affected by them. Neither is there any evidence of increased gingival keratinization from chewing fibrous foods, or that this protects against gingivitis. Eating fibrous foods is not a substitute for careful tooth brushing in modern societies.

Most of the information available on the relationship between nutrients and periodontal disease is old, although interest has recently been regenerated because a possible protective role of antioxidant vitamins has been recognized.

Animal studies have shown that weaning rat pups on a diet deficient in calcium and vitamin $\mathrm{D}$, and sheltering from sunlight, causes inflammatory changes in the alveolar bone, these changes resembling osteoporosis (Oliver, 1969). The ratio of calcium to phosphorus in the diet is also important since secondary hyperparathyroidism causes marked loss of alveolar bone (Henrikson, 1968).

Vitamin A is intimately involved in epithelial maintenance and so deficiency is likely to influence the gingiva. Shaw (1962) reviewed the evidence from animal studies on the relationship between vitamin $\mathbf{A}$ deficiency and periodontal disease and found that gingivitis, gingival hypoplasia, proliferation of crevicular epithelium and resorption of alveolar bone were all associated with a deficiency of vitamin A. Epidemiological studies of humans have also reported relationships between vitamin A status and periodontal disease (Marshall-Day, 1944; Russell, 1963). No study has investigated the effect of the carotenoids on the gingival tissues.

Evidence exists from early animal studies that deficiencies of nicotinic acid, pantothenic acid (Becks et al. 1943), riboflavin (Tomlinson, 1939) and folic acid (Pindborg, 1949; Shaw, 1962) result in gingival inflammation. A World Health Organization epidemiological study in Sri Lanka (Waerhaug, 1967), investigating the relationship between vitamin deficiencies 
and periodontal disease, showed that deficiencies of $B$ vitamins were associated with lower resistance to bacterial irritants. Deficiencies of most B vitamins are rare in modern society and the only $B$ vitamin which is of current interest in relation to periodontal disease is folic acid. Owing to its high cellular turnover rate gingival epithelium is especially vulnerable to folic acid deficiency, which reduces the ability of this tissue to function as a barrier against bacterial insults. Clinical trials of folate in patients with gingival inflammation have shown positive results for both local and systemic use (Vogel, 1977; Vogel et al. 1978; Vogel \& Deasy, 1978; Pack, 1984). During pregnancy gingivitis is common owing to exaggerated response to plaque. It has been suggested that this is due to 'end tissue deficiency' of folic acid. Pack \& Thompson (1980) found that local (mouth rinse) but not systemic (tablet) folic acid supplementation improved gingival health in pregnancy. The Department of Health recommendation that all pregnant women and women planning to become pregnant should receive a daily folate supplement, to avoid neural tube disorders, may have interesting consequences in terms of the incidence of gingivitis during pregnancy.

Vitamin $\mathrm{C}$ has well established functions in the periodontal tissues. It has a key role in collagen synthesis which is relevant to maintenance of the periodontal ligament and alveolar bone and blood vessel walls. The immunological role of vitamin $\mathrm{C}$ is also important in determining host resistance to plaque microorganisms. Animal studies have demonstrated that acute vitamin $\mathrm{C}$ deficiency results in oedema and haemorrhage in the periodontal ligament, osteoporosis of the alveolar bone, tooth mobility, and degeneration of the collagen fibres of the gingivae (Glickman, 1979). Epidemiological studies in humans have failed to demonstrate a relationship between vitamin $\mathrm{C}$ status and gingival health or periodontal destruction (Burrill, 1942; Perlitsh et al. 1961; Russell, 1963; Shannon \& Gibson, 1965). This is probably because gingivitis and periodontitis are of multifactorial aetiology. Patients with severe scurvy can have healthy gingivae, but a deficiency of vitamin $\mathrm{C}$ can exacerbate an existing gingivitis (Hodges et al. 1971). Therapeutic trials of vitamin $\mathrm{C}$ in the treatment of periodontal disease have shown mixed results. Positive results were reported by several investigators (Cohen, 1955; Cowan, 1976; Aurer-Kozelj et al. 1982), which suggests that subjects had suboptimal vitamin status at the onset of the studies. Aurer-Kozelj et al. (1982) reported that a daily supplement of $70 \mathrm{mg}$ ascorbic acid for six weeks produced marked changes in the ultrastructure of the epithelium and connective tissue of the periodontium. Desmosomal junctions between epithelial cells became longer and the contact surface between cells increased. Dachi et al. (1966) found that vitamin C supplementation was unable to reduce gingival sulcus depth in healthy dental students, but it is unlikely that these subjects were deficient. However, Parfitt \& Hand (1963) found that despite poor vitamin $\mathrm{C}$ status, supplementation was unable to improve gingival health.

Vitamin C, and other antioxidant nutrients, may be important in protection of the gingiva from oxidative damage. The implication of free radicals in tissue damage and immunosuppression in other disorders involving chronic inflammation suggests that they may also be involved in periodontal disease. In support of this hypothesis Altman et al. (1992) have shown that toxic oxygen species of neutrophil origin can lyse gingival epithelial cells in vitro. It has also been suggested that free radicals play a role in collagen destruction in periodontitis (Åsman et al. 1994). Collagen destruction may arise as a result of oxidative impairment of the antiproteolytic capacity of $\alpha$-1-antiprotease (Weiss, 1989). Recently Mason et al. (1995) have reported that patients with periodontitis have reduced salivary antioxidant buffering capacity compared to normal controls.

Asman et al. (1994), in an experimental model in the rat, monitored the effect of pharmacological doses of vitamin $\mathrm{E}$ and selenium on collagen degradation. Sponges containing $\left[{ }^{3} \mathrm{H}\right]$ collagen powder were implanted into the nape of the neck of rats. Vitamin $E$ and selenium were injected subcutaneously in the back or directly into the sponges. 
Control animals were given the same volumes of saline. When given simultaneously, systemic and direct injections of vitamin $\mathrm{E}$ and selenium reduced the amount of radioactivity excreted in the urine, but vitamin $\mathrm{E}$ alone had a negligible effect. The authors concluded that "the antioxidants vitamin $\mathrm{E}$ and selenium reduce collagen degradation in experimental granulation tissue and this may be related to the presence of inflammatory cells and their production of free oxygen radicals".

Vitamin E supplementation studies of humans have shown positive results. Goodson \& Bowles (1973) found that $800 \mathrm{mg} \alpha$-tocopherol/d for $21 \mathrm{~d}$ decreased the severity of inflammation in 14 patients with periodontal disease. Cerna et al. (1984) showed that supplementation with $300 \mathrm{mg}$ vitamin $\mathrm{E}$ daily for 12 weeks reduced periodontal inflammation. However, Slade et al. (1976) failed to show a difference in serum concentrations of vitamin $\mathrm{E}$ between patients with periodontal disease and healthy controls. This may be because local antioxidant status bears more relevance to gingival health.

In summary, sugars consumption can increase the volume of plaque - the major aetiological agent in periodontal disease. Reduction in sugars consumption is not, however, a pragmatic approach to plaque control, because the maximum practical reduction in dietary sugar is not capable of preventing gingivitis. Likewise consumption of fibrous foods is not a substitute for tooth brushing. The vitamins have been extensively researched in relation to periodontal disease. Deficiencies of vitamins A, C, E and folate have detrimental effects on periodontal health. Of current interest is the role of folate in preventing gingivitis and further research into the role of free radicals and dietary antioxidants in relation to periodontal disease is expected.

\section{FACTORS IN THE DIET WHICH PROTECT AGAINST DENTAL CARIES}

There are many foods which are non-cariogenic, posing little threat to dental health: there are also foods which have anticariogenic properties, conveying protection to the teeth. These protective factors or food components are also known as 'cariostatic factors', of which fluoride is undoubtedly the most important.

\section{Fluoride}

It is generally held that the use of fluoride is largely responsible for the decline in dental caries observed in developed countries (Glass, 1982; WHO/FDI, 1985). Fluoride is obtained from water supplies, fluoridated dentifrices and, in some countries, other sources such as fluoridated milk and salt. Although the reduction in dental decay observed since the introduction of fluoride may be largely due to non-dietary fluoride such as that in toothpaste, water borne fluoride has undoubtedly played a significant role in the caries decline of recent years, in some countries.

Ingested fluoride has a systemic pre-eruptive effect on teeth during their development. Fluoride, incorporated into the enamel hydroxyapatite crystals during development, increases the resistance of the tooth to caries. Systemic fluoride is also a component of saliva and has a post-eruptive effect locally in the mouth. However, most of the action of fluoride may be attributed to its presence locally in the mouth before it is swallowed or, in the case of toothpaste and mouthrinses, expectorated. In the oral cavity fluoride assists remineralization. During the demineralization process, the more soluble apatite crystals are removed from the enamel and are replaced with more acid resistant fluoridated crystals. Fluoride binds to plaque and is released when the $\mathrm{pH}$ in the plaque falls. The unbound fluoride may then assist in the remineralization process and it has also been shown that 


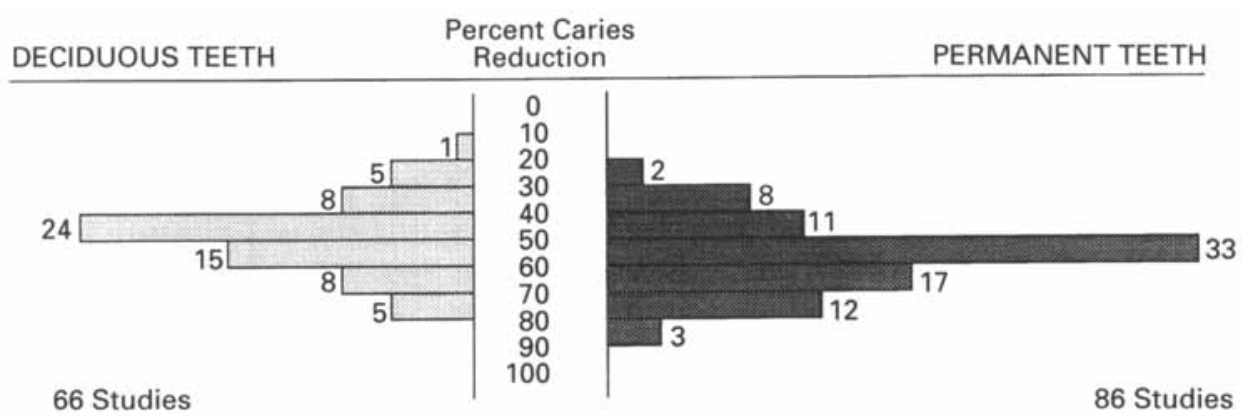

Fig. 1. Percentage caries reduction observed in studies of the effectiveness of artificial fluoridation of water. From Murray et al. (1991) (with permission of Butterworth-Heinemann Ltd).

release of fluoride may dampen down the production of acid (Levine, 1991). Resistance induced by fluoride, locally in the oral cavity, is a factor which counteracts the caries process and is especially effective in the early stages of caries development when the process is still reversible. Fluoride provision, through toothpaste, mouth washes and varnishes, is not strictly dietary, and to review all the evidence for the benefit of fluoride provided by these means is beyond the scope of this review. For a comprehensive account of the role of fluoride dentifrices the reader is referred to Murray et al. (1991) and König (1993). A significant amount of fluoride is, however, provided by the diet, in water and other food items, and the effectiveness of this in caries prevention is summarized below.

Since the 1930 s scientific studies have repeatedly confirmed that optimally fluoridated water produces a dramatic reduction in caries prevalence. However, the first reports of fluoride and teeth concerned consumption of excess fluoride and the consequential development of mottled enamel (McKay, 1916; Dean, 1936), and it was not until the epidemiological studies of Dean et al. (1942) that the relationship between the fluoride concentration in water and dental caries was established. Dean studied 8000 children in 21 USA cities with fluoride concentrations in water supplies ranging from 0 to 3 p.p.m., and was able to establish a clear inverse relationship between dental caries and concentration of fluoride. The subsequent studies carried out in many countries on both permanent and deciduous teeth confirmed the original findings of Dean, that the relationship between fluoride concentration in the water supply and dental caries was J-shaped (Møller, 1965). From the results of numerous epidemiological studies the optimum fluoride concentration for water supplies was set at 1 p.p.m., in temperate climates, which was a balance between levels which prevent caries and levels which cause mottled enamel.

Few areas in the United Kingdom have water supplies which naturally reach the optimum fluoride concentration and since the early 1960 s some areas have been artificially fluoridated to a concentration of 1 p.p.m. Murray et al. (1991) have summarized the benefits shown in 86 studies investigating the effectiveness of adding fluoride to the water supply and these findings are presented in Fig. 1. There are, however, some authorities who are reluctant to adjust the fluoride concentration and at present only $12 \%$ of England has optimally fluoridated water.

Several studies have investigated the effectiveness of fluoridating school water supplies. The rationale for such studies was based on observations that children who lived in low fluoride areas, but attended schools in areas where the water was naturally high in fluoride, had less caries than children from the same residential area who attended schools whose water supply was low in fluoride (Barron \& Lewis, 1968). There have been three major intervention studies, all in a low fluoride area of the USA (Horowitz et al. 1968, 1972; 
Heifetz et al. 1983). All have demonstrated a substantial reduction in dental caries following fluoridation of school water, at levels approximately 4.5 times the optimum level (which takes into account that not all water is consumed at school). Following 12 years of fluoridation, Heifetz et al. (1983) reported a reduction in dental caries of up to $47 \%$. Despite these substantial improvements in dental health, school water fluoridation in the USA has been abandoned owing to maintenance problems and running costs.

Salt is used in several countries as a dietary vehicle to which fluoride is added. It was first fluoridated in Switzerland almost half a century ago (Wespi-Eggenberger, 1948) and today over $70 \%$ of salt purchased in Switzerland contains fluoride (Murray et al. 1991). Despite the widespread use of fluoridated salt its effectiveness is difficult to measure because there are many other preventive programmes in operation in Switzerland. Nonetheless, data published by de Crousaz et al. (1985) following 12 years use of fluoridated salt ( $250 \mathrm{mg} \mathrm{F} / \mathrm{kg}$ salt) by children in four age groups ranging from 8 to 14 years showed that caries experience was consistently lower compared to control children who had consumed non-fluoridated salt. Toth (1976) reported the effectiveness of fluoridated salt in Hungary. Following 8 years of salt fluoridation DMFT was decreased by $39 \%$ in 6 -year-old children but although this was substantial it was not as effective as the reduction in caries observed following fluoridation of water supplies. Recently, Menghini et al. (1995) have published results of a fluoridation programme in the Swiss Canton of Glarus. Salt fluoridation was introduced in this area between 1974 and 1976 and has been used since by bakeries and households. Caries prevalence in schoolchildren from this Canton between 1974 and 1992 was reduced by $80-85 \%$. In 1974 the mean DMFT was 6.5 whereas in 1992 it was $1 \cdot 1$. Fluoridation of salt as a public health measure for caries prevention is increasing. Health education may lead to reduced salt consumption (Department of Health, 1994c), but the concentration of fluoride added to salt can be adjusted upwards to counteract any such reduction in salt consumption.

Because children are encouraged to drink milk, it has been considered a suitable vehicle for fluoride. Fluoride from milk is as easily absorbed as fluoride from water (Villa $e t$ al. 1989), but binding of fluoride to calcium or protein present in milk may reduce the topical effect of fluoride in the mouth (Duff, 1981). Rugg-Gunn et al. (1976) did not find an increase in plaque fluoride concentration after children had consumed fluoridated milk, and Zahlaka et al. (1987) reported no increase in enamel fluoride in children who had consumed fluoridated fruit milk for three years. Nonetheless, fluoridated milk has been shown to have a caries preventive effect in rats (Poulsen et al. 1976) and humans. In clinical trials of fluoridated milk positive results have been obtained in terms of caries reduction (Rusoff et al. 1962; Ziegler, 1962; Stephen et al. 1981, 1984). The only trial conducted in the UK was a 5 year study of Glaswegian children initially $4 \frac{1}{2}-5 \frac{1}{2}$ years old who each received $200 \mathrm{ml}$ milk with $(n=50)$ or without $(n=56) 7$ p.p.m. fluoride daily. The fluoridated group had a mean DMFT of 3.8 which was substantially lower than that of the controls who had a DMFT of 6.6 (Stephen et al. 1981). Similar findings to those with fluoridated pure milk have been observed when cocoa milk has been supplemented with fluoride (Banoczy et al. 1983, 1985; Leggett et al. 1987) and Gedalia et al. (1981) reported beneficial caries preventive effects following daily consumption of fluoridated fruit juice. A more detailed review of milk fluoridation has been published by Murray et al. (1991).

In summary, water borne and food borne fluoride has been shown to be very effective in reducing caries development, yet despite this only $12 \%$ of England has optimally fluoridated water and use of fluoridated food in this country is uncommon. Fluoridation of school water is technically complicated and, despite positive results, has been abandoned as a public health measure. All the reported trials of milk and salt fluoridation have shown substantial caries preventive effects, especially when consumption begins before eruption of 
the permanent teeth, but as yet fluoridated milk has not been introduced as a public health measure on a community basis.

\section{Other protective factors}

One of the first foods reported to be anticariogenic was milk (Sperling et al. 1955; Shaw et al. 1959). Milk contains lactose which is moderately cariogenic, but it also contains protective factors, so without added sugars milk can be considered non-cariogenic (Department of Health, 1991). Calcium and phosphorus in milk help prevent enamel demineralization. Animal studies have shown that supplementation of a cariogenic diet with milk substantially reduced dental caries incidence (Reynolds \& Johnson, 1981). Plaque pH studies have shown that milk causes only a negligible decrease in plaque pH (Jenkins \& Ferguson, 1966; Edgar et al. 1975; Rugg-Gunn et al. 1985), enamel slab studies have shown that milk solids can reduce the cariogenic potential of sugar-containing foods (Thompson et al. 1984), and Bowen et al. (1991) have shown that milk does not produce dental caries even when given in a caries promoting environment.

Human milk contains more sugar than bovine milk ( $7 \%$ compared with $4.8 \%$ ) yet epidemiological evidence (King, 1940; Tank \& Storvick, 1965; Holt et al. 1988) and enamel slab experiments (Araujo et al. 1995) suggest that breast milk is generally non-cariogenic. A few reports have related breast feeding to dental caries, when feeding has been prolonged (usually over 2 years), on demand and at night (see Hackett et al. (1984) for a review).

There has been recent concern that soya infant formula may be cariogenic owing to the presence of glucose syrups. Soya milks contain fewer mono- and di-saccharides although they contain saccharides of longer chain length, the cariogenicity of which has not been clearly defined. Moynihan et al. (1995b), in a plaque pH study in adult volunteers, found no significant difference in the acidogenic potential of soya infant formula and infant milk. Soya infant formula is casein free and casein has been shown to be cariostatic (Bavetta \& McClure, 1957; Reynolds \& Black, 1987). However, it is likely that the mode of consumption is the major determinant of caries and this has recently been highlighted in the COMA report Weaning and the Weaning Diet (Department of Health, 1994b).

The fat in milk aids oral clearance, but the relative retention times of milks of varying fat contents have not been determined. It is unlikely that even fat free milk causes caries owing to calcium, phosphorus and other factors such as casein. Casein has been shown to adsorb to the enamel surface, protecting against demineralization (Pearce \& Bibby, 1966) and addition of casein to animal diets decreases the development of caries (Bavetta \& McClure, 1957; Holloway et al. 1961; Reynolds \& Black, 1987). Unfortunately, at concentrations that inhibit caries, casein is unpalatable to humans. However, the phosphopeptides present in casein, which are responsible for the anticaries action, may be extracted from the casein and these do not have an adverse taste effect (Reynolds \& Black, 1989).

Evidence from animal studies (König, 1966), plaque pH studies (Rugg-Gunn et al. 1975; Imfeld et al. 1978; Jensen et al. 1984; Jensen \& Welfel, 1990) and enamel slab experiments (Silva et al. 1986; Reynolds, 1987; Jensen \& Welfel, 1990) have all shown that cheese has anticaries properties. Several mechanisms have been proposed for this action, including stimulation of saliva flow, increasing the calcium content of plaque (Rugg-Gunn et al. 1975; Jenkins \& Hargreaves, 1989), and adsorption of protein to enamel (Higham \& Edgar, 1989). At present no clinical trials of the caries protective effect of cheese have been reported.

People who consume diets high in unrefined plant foods have been shown to have a low caries prevalence, despite high carbohydrate diets. This observation has generated much research into protective factors in unrefined plant foods. A review on the anticaries actions 
of organic and inorganic phosphates has been published (Lilienthal, 1977). Inorganic phosphates act through a local common ion effect: a high concentration of inorganic phosphate at the enamel surface promotes remineralization as opposed to demineralization. Organic phosphates protect by adsorption to the enamel surface, forming a physical barrier against acid attack (Rugg-Gunn, 1993). Evidence exists, from over 100 animal experiments, that inorganic phosphates reduce dental caries experience in rats fed cariogenic diets (see Nizel \& Harris, 1964). Averill et al. (1966) investigated the effect of $2 \%$ dicalcium phosphate on the teeth of 6-13-year-old children in Brazil who had previously been on a low calcium diet. A reduced incidence of dental caries over the 20 month study period was reported. Furthermore, addition of dicalcium phosphate to chewing gum counteracts the effect of sugar (Richardson et al. 1972). However, studies in which phosphate supplemented sweets have been tested against unsupplemented sweets have found no protective action (Ashley et al. 1974; Rankine et al. 1989). Positive results have been obtained from studies in which the diet has been supplemented with chewing gum containing sodium trimetaphosphate (Finn et al. 1978), but concern has been expressed that the amount of sodium trimetaphosphate required in order to reduce caries may result in undesirably high sodium intakes and an imbalance of calcium and phosphate in the diet (Shaw, 1980). No clinical trials of calcium trimetaphosphate have been reported.

Animal studies of the anticaries properties of calcium sucrose phosphate and calcium glycerophosphate have shown positive results (Lilenthal et al. 1966; Bowen, 1972; Grenby \& Bull, 1975), but the effectiveness of these organic compounds was never established in human clinical trials. Phytate has been identified as the most active anticaries factor in unrefined food. Phytate adsorbs to the enamel surface and prevents acid dissolution (Magrill, 1973). It is most effective when added to the diet rather than being present as a food component, because phytate in bran takes too long to be released in the mouth (Jenkins \& Smales, 1966). Moreover, addition of wheat bran to the diet is not recommended because it reduces the absorption of trace elements (Jenkins, 1978).

In the Vipeholm study, patients in the chocolate group developed fewer caries, which led to speculation that chocolate contained protective factors. Early animal studies supported this hypothesis (Stralfors, 1966). In 1986 cocoa factor was extracted from chocolate (s'Gravenmade \& Jenkins, 1986) and was shown to be effective in vitro. The extraction procedure was, however, expensive and the factor was therefore a less cost effective anticaries supplement than fluoride. Although chocolate contains both casein and cocoa factor, it is doubtful if these protective factors override the detrimental effect of its high sugar content.

In summary, foods which contain protective factors against dental caries include milk and cheese, both of which have been studied extensively. Chocolate contains protective factors but practical constraints make these of limited use. Plant foods contain phosphates and phytate which have been shown to convey protection, and fibrous foods which require thorough chewing stimulate saliva, thereby increasing buffering capacity.

\section{DENTAL CARIES - THE ROLE OF DIETARY SUGARS}

Periodontal disease remains the predominant cause of tooth loss in adults. However, for the UK population as a whole, dental caries is the primary cause of tooth loss; it is characterized by the destruction of the hard structures of the teeth. The caries process involves the presence of oral bacteria and a dietary substrate (sugars), saliva availability and composition, and enamel structure. Bacteria present in dental plaque, e.g. Streptococcus mutans (S. mutans), metabolize dietary sugars to produce organic acids. When the $\mathrm{pH}$ of the environment surrounding the teeth falls jelow a critical $\mathrm{pH}(\sim \mathrm{pH} 5.5)$, demineral- 
ization of enamel may occur. Saliva, the protective biological fluid in the oral cavity, buffers the acid produced and raises $\mathrm{pH}$ to levels at which demineralization does not occur. The buffering action of saliva acts mainly on the surface of the plaque and its rate of diffusion will determine whether it penetrates the entire plaque depth. The rate of diffusion applies equally to sugar substrates - the more sugar there is present, the faster it diffuses into the plaque depth. The caries process is therefore dependent upon a balance of several factors; the most important, which has undoubtedly received the most attention, is probably dietary sugars.

The evidence linking dietary sugars to caries comes from a number of different types of study, namely: human intervention studies, human observational studies, animal studies, enamel slab experiments, plaque $\mathrm{pH}$ experiments and incubation experiments. Collated evidence from each study type gives an overall picture of the cariogenic potential of sugars and other foods.

\section{Epidemiological surveys}

Worldwide epidemiological investigations have shown that a relationship exists between per capita sugars availability and dental caries experience in both primary and permanent dentition (Marthaler, 1979; Sreebny, 1982). When interpreting the findings of worldwide studies, one must take into consideration the possibility that different age groups may consume different proportions of the nation's sugar supply, and also that sugars supply may not equate with sugars consumption. It is also possible that in such studies the relationship between sugar supply and dental caries could reflect other factors in the diet (for which sugar is a proxy). It must also be appreciated that within a country dental caries will vary considerably. Despite their limitations, such studies have shown some findings of interest. A commonly quoted study is that of Sreebny (1982), upon whose findings the current recommendations for sugars intake are partly based. In this study of 12-year-old children from 47 countries, Sreebny showed that for every $20 \mathrm{~g} / \mathrm{d}$ increase in sugars supply there was an increase in DMFT of 1 . In the 21 countries which had a sugars supply of less than $50 \mathrm{~g} / \mathrm{d}(18.25 \mathrm{~kg} /$ year), caries experience was consistently low ( $<3 \mathrm{DMFT}$ ). The correlation coefficient for sugars intake and DMFT was 0.72 , indicating that most of the variation in caries could be accounted for by availability of sugars.

More recently Woodward \& Walker (1994) have published data on per capita sugars consumption in 12-year-old children from 90 countries. DMFT increased with sugars consumption, but the rate of increase was lower than that found by Sreebny (1982). Twenty-three of the 26 countries with a sugars intake below $18.25 \mathrm{~kg} /$ year had a DMFT of below 3.0, but so did 34 of the 64 countries with a sugars consumption of above $64 \mathrm{~g} / \mathrm{d}$. When data from 29 industrialized countries were analysed separately, there was no evidence of a sugars-caries relationship. However, the relationship between sugars intake and caries is sigmoid and the absence of a significant correlation between sugars intake and caries in industrialized countries may be because these countries lie on the upper flattened area of the sigmoid curve. The authors concluded that in Western countries factors such as non-sugars carbohydrate, cariostatic agents and fluoride may explain variations in caries prevalence and should be considered when making recommendations for caries control.

Developing countries and isolated communities which, through increased trade with westernized communities, have become exposed to sugars, after having a diet free from refined sugars, experience a significant increase in dental caries. In the 1930s caries was virtually unknown in the Inuit living in Greenland. With increased trading and the introduction of sugars to the diet, by 1977 the mean DMFT of 14-year-old children was 19 - among the highest in the world (Jakobsen, 1979). Similar occurrences have been observed in Ethiopia (Olsson, 1978, 1979), French Polynesia (Baume, 1969) and Ghana (MacGregor, 
1963) and studies of Nigerian communities have shown that the increase in severity of dental caries recorded over the last 25 years can be explained by changes in sugars consumption (Akpata, 1979; Olojugba \& Lennon, 1987, 1990). Although the increase in sugars availability was often associated with an increase in the availability of refined flour, the latter is far less cariogenic.

Studies of groups of people who habitually consume a small amount of dietary sugars have generally shown a low prevalence and severity of dental caries. Such groups include children living in children's homes (Harris, 1963; Silverstein et al. 1983), children with hereditary fructose intolerance (Newbrun, 1989), Seventh-Day Adventists (Glass \& Hayden, 1966) and children of dentists (Bradford \& Crabb, 1961, 1963; MacDonald et al. 1981). The Hopewood House Study (Harris, 1963) investigated 12-year-olds in an Australian children's home who ate a virtually sugar-free, unrefined lacto-vegetarian diet. At the age of 12 years $46 \%$ were caries free compared to $1 \%$ of 12 -year-olds from state schools. This study was carried out before the use of fluoride toothpaste but, being unrefined, the diet of the children in Hopewood House was likely to be higher in other protective factors. Early studies of diabetics report a relatively low caries experience (Sterkey et al. 1971; Bernick et al. 1975). More recent studies have found no differences in DMFT between diabetic and non-diabetic persons (Sarnat et al. 1985; Albrecht et al. 1988), which has been attributed to increased consumption of dietary starch by diabetics. Prior to 1980 diabetics were prescribed a diet low in all carbohydrate, but today a diet high in carbohydrate but low in simple sugars is recommended. Dietary starch and dental caries will be considered in more detail later. Tavares et al. (1991) have, nonetheless, reported a lower prevalence of root caries in diabetic adults compared to controls.

Attempts have been made to relate the amount of sugars consumed to caries prevalence during and after the war years. A thorough literature survey by Sognnaes (1948) reported a reduction in prevalence and severity of caries in 27 wartime studies. Takahashi (1961) reported a close correlation between annual caries incidence in the first molars and annual sugars consumption between 1941 and 1958 in Japanese children. A similar relationship was reported by Marthaler (1967) in data collected from Switzerland, Norway and New Zealand. However, in many studies of this type, age specific information on sugars intake is unavailable, and it is likely that there were many other wartime dietary changes such as a decrease in intake of refined starchy foods.

Persons who habitually have a high sugars consumption have been shown to have a higher incidence of dental caries, for example, sugar cane cutters (Driesen \& Spies, 1952; Kunzel et al. 1973; Frencken et al. 1989) and workers in the confectionery industry (Anaise, 1978; Katayama et al. 1979). However, a study of 12 -year-old African children on a sugar plantation found that despite a six-fold higher sugars availability, caries scores were not higher than those of controls. No information on actual intake of sugars by these children was reported (Rugarbaum et al. 1990).

Numerous cross-sectional studies attempting to indicate a relationship between sugars consumption and dental caries have been carried out, from which Rugg-Gunn (1993) has presented a comprehensive summary. The experimental design varies widely between crosssectional studies and often only the correlation coefficient and not the absolute dental caries experience is reported. Even when significant relationships have been found absolute differences in dental caries experience have sometimes been small (e.g. Mansbridge, 1960). In other studies large differences in absolute values for decayed, missing and filled teeth (deciduous) have been found between high and low sugar consumers but numbers have been insufficient for statistical significance (e.g. Sundin et al. 1983). The main disadvantage of cross-sectional studies is that rather than assessing lifelong sugar consumption habits they try to relate dental caries experience at one time point to current diet usually assessed 
over a matter of days. The caries experience being measured may have occurred several years previously and diet may have changed considerably during this period. Crosssectional studies are, however, a more suitable approach for the study of younger children, whose teeth have erupted over the preceding few years and whose sugars eating habits may have not changed appreciably since the time of eruption. Granath et al. (1978), in a study of 4-year-old children, found a significant relationship between sugars consumption between meals and dental caries, which was independent of fluoride intake or oral hygiene practices. Children with low sugars intakes between meals had significantly fewer caries than children with high sugars consumption between meals. Studies of older children have found the relationships between oral hygiene (Persson et al. 1984), water fluoridation (Hausen et al. 1981, Kleemola-Kujala \& Rasanen, 1982), and S. mutans (Kristofferson et al. 1986) and dental caries to be more important than the relationship between sugars intake and dental caries.

Several incremental observational studies have found significant relationships between sugars intake or sugars eating habits and caries development (Rugg-Gunn et al. 1984; Burt et al. 1988; Drummer et al. 1990). In a two-year study of 405 children age 11-12 years, correlations between dietary variables and dental caries increment were generally low. However, the 31 children who consumed the most total sugars developed $56 \%$ (0.9 DMFT/person annually) more dental caries than the 31 children who had the lowest sugars intake. The children who developed no caries throughout the study period (RuggGunn et al. 1984) had significantly lower intakes of confectionery $(P<0.05)$, sugared coffee and drinking chocolate $(P<0.05)$.

Human intervention studies in the field of diet and dental caries are rare owing to ethical problems and the difficulty of placing groups of people on strict dietary regimens for long periods of time. The only two studies from which conclusive evidence can be drawn are the Vipeholm study (Gustaffson et al. 1954) and the Turku study (Scheinin \& Mäkinen, 1975).

The Vipeholm study, in a Swedish mental institution between 1945 and 1951, investigated the effect on dental caries activity of consuming sugar-rich foods of varying stickiness, at mealtimes only or at mealtimes and between meals. The main findings were: consumption of sugar, even at high levels, is associated with only a small non-significant increase in dental caries if the sugar is taken up to four times a day at meals and none between meals, and consumption of sugar-rich foods both between meals and at meals is associated with a marked increase in caries.

The Turku study, carried out in Finland in the 1970s (Scheinin \& Mäkinen, 1975; Scheinin, 1979), showed that nearly total substitution of sucrose in the diet with xylitol resulted in substantial reduction in the incidence of dental caries. However, total substitution is not practical and the effect of partial substitution has not been clearly defined. This is because no study has investigated the effect of partly substituting the sugar in an existing diet (as was the case with the Turku study). Studies have generally compared the effect of giving a sugared $v$. a non-sugared product in addition to the usual diet; for example comparing caries increment between groups receiving sugared chewing gum compared to a gum containing polyols. Most studies of this nature have nonetheless reported a lower caries increment in the groups receiving the sugar free products. Comprehensive reviews of such trials have been published (Edgar \& Geddes, 1990; RuggGunn, 1993).

\section{Animal studies}

Animal studies have been valuable in helping to determine the relationship between frequency or amount of sugars consumption and dental caries because diets can be given in defined amounts at precisely timed intervals. Diets containing some sugar produce more 
dental caries than diets containing no sugar, but further increases in dental caries have not always been observed when the concentration of sugar increases above $10 \%$. The composition of the base diet influences the cariogenic potential of the sugar added. Shaw (1979) found that five times as much sugar was needed to reach the same level of caries when the base diet was high fat as opposed to high starch. The conflicting results of other animal studies appear to be due to differences in base diets and to whether or not the animals have been superinfected with S. mutans (Green \& Hartles, 1970; Huxley, 1971, 1977). Hefti \& Schmid (1979) heavily superinfected their rats with $S$. mutans and Actinomyces viscosius and found that dental caries severity increased with increasing sugar concentration although the increase in severity fell with sugar concentrations above $40 \%$.

Animal studies have compared the relative cariogenicity of different sugars. A theory existed that sucrose was uniquely cariogenic because consumption resulted in dextran formation and increased plaque volume. Studies in rats have shown sucrose to be more cariogenic than fructose, maltose, lactose or glucose (Guggenheim et al. 1966; Grenby, 1973), but the rats were superinfected with $S$. mutans which preferentially take up and utilize sucrose. So compared to other sugars the cariogenicity of sucrose was likely to have been exaggerated. Colman et al. (1977) found sucrose, fructose and glucose to have similar cariogenicity in monkeys. These findings, together with those of Schemmel et al. (1982), do not support the idea that sucrose is relatively more cariogenic owing to increased dextran formation.

A comprehensive review of animal experiments in relation to sugars and dental caries (Shaw, 1983) drew the main conclusions that (1) sugar must be present in the oral cavity for caries to occur, (2) sugar in the oral cavity in the absence of other nutrients is capable of causing lesions if a cariogenic flora is present, (3) increasing both the frequency of eating and the length of time that the diet is available hastens the initiation and progression of carious lesions, and (4) all mono- and di-saccharides tested cause carious lesions in cariesprone animals if an appropriate flora is present.

\section{Enamel slab and plaque $p H$ studies}

Enamel slab experiments involve the use of intra-oral appliances which hold slabs of enamel in the mouth for a period of 1-6 weeks. They enable the cariogenic effect or the remineralizing effect of a substance to be monitored in situ. Lesion hardness is measured by microhardness tests (Koulourides et al. 1976) and iodine dye permeability (Brudevold et al. 1984). Appliances can be removed from the mouth several times a day and placed in the test solution at body temperature (Koulourides et al. 1976), or foods can be eaten with the appliance in place (van Herpen \& Arends, 1986). Few enamel slab studies have been reported in comparison to other tests of cariogenicity. Koulourides et al. (1976) demonstrated that when enamel slabs were placed in sugar solutions several times daily, the plaque microorganisms present on the slabs were capable of metabolizing the sugars with the subsequent production of acid and demineralization of the enamel slab. Tehrani et al. (1983) showed that increasing the concentration of sugars increased the extent of demineralization.

Plaque $\mathrm{pH}$ before, during and after eating gives a measure of the acidogenic potential of a foodstuff. Acidogenicity is the ability of a foodstuff to be metabolized to acid whereas cariogenicity is the ability of a foodstuff to cause dental caries. Acidogenicity and cariogenicity are likely to be strongly correlated, with only the presence of 'protective factors' confusing their close relationship.

Plaque pH may be monitored in situ with electrode probes (Stephan, 1940; Harper et al. 1985). Alternatively electrodes may be fitted into oral appliances to be worn for several days to enable plaque to collect, and $\mathrm{pH}$ recordings made either via wires coming from the 


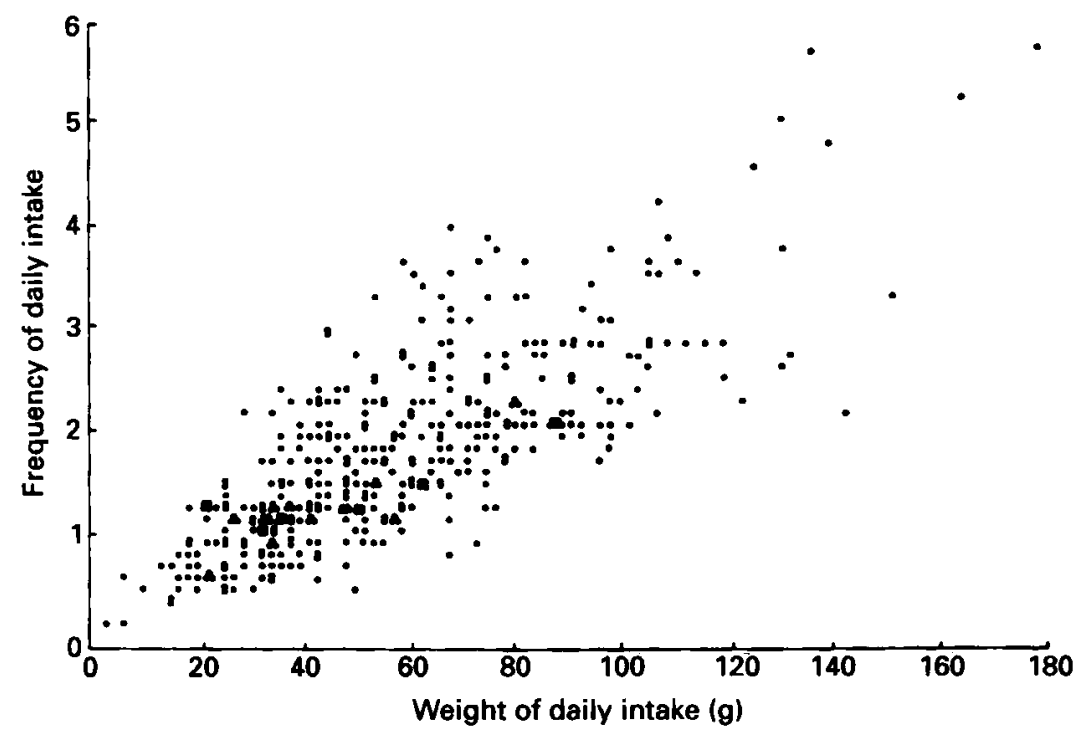

Fig. 2. Plot of the frequency of intake per day against the weight consumed per day, of confectionery, by 405 12-14-year-old children in north-east England (Rugg-Gunn et al. 1984). The correlation coefficient is $+0 \cdot 77$. Reproduced from Rugg-Gunn (1993), with permission of Oxford University Press.

mouth or by radiotelemetry (Imfeld, 1977). Another method, the 'harvesting method', involves the removal of a pooled plaque sample from all areas of the mouth, and measurement of the $\mathrm{pH}$ in vitro using an electrode (Fosdick et al. 1941). Each method has advantages and disadvantages (Rugg-Gunn, 1993).

Studies of sucrose-containing foods have demonstrated falls in $\mathrm{pH}$ below the level (pH 5.5) at which demineralization is thought to occur (Graf, 1970; Rugg-Gunn et al. 1978; Edgar, 1985). Plaque $\mathrm{pH}$ studies have also been used to distinguish between the effects of different sugars and different concentrations of sugar. Frostell (1973), using the harvesting method, found a lower $\mathrm{pH}$ with $50 \%$ compared with $5 \%$ sucrose, but no fall with $2.5 \%$ sucrose. Imfeld (1977), using an indwelling electrode, found similar decreases in plaque $\mathrm{pH}$ with $2.5,5$ and $10 \%$ sucrose solutions, which may be due to an 'all or nothing' response of indwelling electrodes. Frostell (1973) showed that lactose produced less severe decreases in $\mathrm{pH}$ compared to sucrose, glucose or fructose which showed equal acidogenicity, and these findings have been confirmed by Imfeld (1977).

Incubation studies to test the ability of plaque microorganisms to metabolize a test food in vitro have shown that all sugars can be fermented by them (Bibby \& Krobicka, 1984).

\section{Frequency and amount of sugars intake}

There is very strong evidence that frequency of sugar intake is important in the development of dental caries. The more frequently sugars are consumed the more often the $\mathrm{pH}$ in the oral cavity drops to a level below that at which demineralization occurs. Animal studies clearly show that dental caries increases with increasing frequency of sugars intake independently of the amount of sugars consumed (König et al. 1968). The time interval between meals has also been shown to be an important factor. Firestone et al. (1984) carried out an experiment in which animals ate a cariogenic diet in 18 portions a day. Meals were consumed either in three groups of six portions with no interval between the six portions in each group, or with a $30 \mathrm{~min}$ period between each of the 18 portions. The latter resulted in greater development of dental caries. In the Vipeholm study subjects who ate sugary 
foods between meals as well as at meals developed more caries than subjects who ate sugar only at mealtimes (Gustaffson et al. 1954).

Frequency of sugars consumption is undoubtedly an important factor in caries aetiology, but there is also evidence that amount of sugars consumed influences dental caries development independently of frequency, suggesting that both factors are important (Rugg-Gunn, 1993). Mikx et al. (1975) carried out a study in which five groups of rats received diets of varying sugar concentration and found a significant positive correlation between the sucrose concentration and the incidence of caries. Hefti \& Schmid (1979) found that there was also a tendency towards higher eating frequencies on the higher sugar diets.

In most epidemiological studies weight of sugars consumed rather than frequency was measured - for example the studies of Sreebny (1982). It is likely that a high positive correlation between amount and frequency of eating exists (Fig. 2) and some evidence for this is provided by the study of Rugg-Gunn et al. (1984). In terms of nutrition health education this implies that advice to reduce the frequency of consumption will be concordant with a decrease in amount of sugars consumed. Nutrition health education should focus on such messages which are simple yet pragmatic.

In summary, there is a wealth of information (over 1000 published articles) on the relationship between dietary sugars and dental caries, which comes from epidemiological, animal, plaque $\mathrm{pH}$ and laboratory studies. Reduction of sugars intake, especially the frequency of intake, remains an important goal for health education.

\section{DENTAL CARIES - THE ROLE OF DIETARY STARCH}

The evidence of sugars as an aetiological agent in dental caries has resulted in the current Department of Health recommendations to reduce the consumption of sugars (non-milk extrinsic - i.e. those sugars that are not located within the cellular structure of the food, excluding milk sugars) to under $10 \%$ of energy intake and to replace the energy with starchy foods (Department of Health, 1991). It has, however, been suggested that all carbohydrates are capable of undergoing fermentation in the oral cavity and are therefore capable of causing dental caries. By reviewing the evidence relating starch to dental caries the likely impact of the Government's advice can be judged.

The only data from an observational study between countries compared DMFT to the per capita consumption of cereals and not starchy foods as a whole. However, this study showed that correlations between cereals intake and DMFT were low and not statistically significant (Sreebny, 1983).

Little evidence of the effect of starch on dental caries can be drawn from studies in which the prevalence of dental caries has been observed before and after a dietary change, since refined starch has always been introduced at the same time as sugar. In the study of Fisher (1968) inhabitants of Tristan da Cunha were introduced to sugar and refined flour in 1942, which resulted in deterioration of the islanders' teeth. This cannot be solely blamed on the introduction of sugar; however, it is of interest that prior to 1942, when few caries existed, the staple food was cooked potatoes.

Countries which have staple diets high in starch and low in sugars have been reported to have few caries, suggesting the non-cariogenic nature of starch (Afonsky, 1951; Russell et al. 1960). However, Schamschula et al. (1978) reported a moderate level of dental caries in Melanesian subjects age 12-24 years living in Papua New Guinea. The diet of these people was high in starch, as the staple food was sago, and low in sugars, yet DMFT values of up to 22 were reported.

People with hereditary fructose intolerance, who habitually consume a diet low in sugars but high in starch, have a low caries experience (Newbrun et al. 1980; Newbrun, 1989), 
indicating that starch is not particularly caries promoting. Similar findings (van Houte \& Duchin, 1975) have been reported for children deficient in sucrase (EC 3.2.1.48) and isomaltase (EC 3.2.1.10).

Fewer cross-sectional studies have been reported on the relationship between starch intake and dental caries compared to sugars intake, and none has shown a positive relationship between starch and caries (Martinson, 1972; Hankin et al. 1973; KleemolaKujala \& Rasanen, 1979). In a longitudinal dietary study of adolescents, Rugg-Gunn et al. $(1984,1987)$ showed no correlation between intake of starch and DMFT.

Much information on the relationship between dietary starch and dental caries has come from animal studies. The animal species or strain varies between studies, as does the caries scoring system and the type of base diet which is sometimes given by gastric intubation (Bowen et al. 1980). A comprehensive review of the earlier work was reported by Grenby (1967), from which he concluded that the most commonly held view was that starch and glycogen were far less cariogenic than glucose. Most of the earlier studies were of uncooked starch, which is perhaps not applicable to the present-day human diet. The form in which the starch is eaten is important. The more refined the starch is the more easily it will be digested by salivary amylase (EC 3.2.1.1) in the oral cavity. The more fibrous the nature of the starchy food the more chewing it will require. It has been suggested that the increased requirement for chewing will stimulate salivary flow and help to neutralize the acid produced (Caldwell, 1970; Rugg-Gunn, 1993) although there is a paucity of evidence for this beneficial affect of fibre.

Early studies comparing the effects of uncooked and cooked starches have found that cooked starches result in significantly more caries (Grenby, 1965; Green \& Hartles, 1967). Grenby \& Paterson (1972) showed that when rats were fed a diet containing $24 \%$ sucrose and $42 \%$ white flour the level of caries was moderate to low but when the diet was baked into biscuits the incidence of caries rose significantly. This was probably because the baking process caused the starch partly to break down into smaller chain saccharides. In a study by Bowen et al. (1980), in which rats were fed by gastric intubation and only received test foods orally, starch was shown to produce $45 \%$ of the fissure caries seen with a sucrose diet. In this study potato crisps caused $84 \%$ of the fissure caries seen with sucrose diets, which was greater than caramel $(73 \%)$ and chocolate (72\%). Firestone et al. (1982), using the gastric intubation technique, gave rats 18 feeds/d with either sucrose, cooked starch, a mixture of sucrose and starch or alternate feeds of sucrose and starch. Cooked starch was cariogenic but not to the extent of sucrose. Alternating meals of sucrose and starch was as cariogenic as sucrose alone. The mixture of sucrose and starch was as cariogenic, if not more so, than sucrose alone. The findings suggest that cooked starch is cariogenic especially if the diet contains sucrose. Schmid et al. (1987) found that cooked and uncooked starch show a low cariogenicity when fed on their own, but that addition of $20 \%$ sucrose increased caries prevalence more in the cooked starch group than in the uncooked starch group. The mechanism for this observation is unclear.

Grenby (1990) investigated the cariogenic potential in rats of a variety of starchy foods. A sucrose control group developed the most caries followed by a rich tea biscuit group, then a potato crisps group. The groups with fewest caries were those which consumed wheat starch or salted peanuts. He concluded that manufacturing processes which cause extensive hydrolysis of starch render it more available for oral fermentation. Manufacturing starchy foods will cause starch granules to burst and enable the breakdown of the polysaccharide chains to smaller saccharide chain lengths. These smaller carbohydrate chains may be further metabolized in the oral cavity, by the action of salivary amylase, to yield chains of glucose units short enough to be taken up by the oral bacteria and metabolized to acid. Extrapolation of results from studies in rats to man is complicated 
owing to the powdered form in which the rat diet is consumed, and between species differences in oral microflora and saliva composition. For example, the saliva of rats has less buffering capacity than that of primates including humans (Beighton \& Hayday, 1984). Cooked wheat starch has been shown to exhibit low cariogenicity in non-human primates (Beighton \& Hayday, 1984). There is no evidence that oral flora of rats or their salivary glands adapt to metabolize starch more rapidly after several generations of rats have been given high starch diets.

Enamel slab studies show that starches produce less demineralization than sugar-rich foods (Huang et al. 1981; Bibby et al. 1983). Brudevold et al. (1985) compared the effect of rinsing with $10 \%$ solutions of cooked or raw starch on enamel demineralization. Cooked starch increased iodine permeability to a greater extent than raw starch, but the increase in permeability caused by sucrose was over 4-fold that caused by cooked starch.

Early plaque pH studies showed increased acidogenicity of sucrose and sugarscontaining foods compared to starchy foods (Ludwig \& Bibby, 1957; Mörch, 1961), and increased acidogenicity of cooked starch compared to uncooked starch (Nerf, 1967; Frostell, 1972). Studies in which snack foods have been ranked according to their acidogenic potential using the sampling technique (Edgar et al. 1975; Rugg-Gunn et al. 1978) have generally found starchy snacks such as crisps and bread to be towards the low end of the acidogenic scale. Studies published by Imfeld (1983), using an indwelling glass electrode, have shown decreases in plaque $\mathrm{pH}$ to values below 5.0 for popcorn, breakfast cereals, potato crisps, rolled oats, white bread and minute (Quick Cook) rice. However, all the foods were tested in one caries-prone subject. It has been argued that the bacterial colonization on the glass electrode differs from that on enamel and that the electrode is hyper-responsive (Newbrun, 1984), giving an 'all or nothing' response whereby any carbohydrate food causes a maximum fall in $\mathrm{pH}$ (Edgar, 1985). These factors limit the application of indwelling electrodes to the comparison of acidogenicity between foods. Using the harvesting method, Bibby et al. (1986) observed that although the minimum $\mathrm{pH}$ reached for starchy foods such as white bread, crisps and cornflakes was similar to sugary foods, the times to reach minimum $\mathrm{pH}$ were longer. In general, plaque $\mathrm{pH}$ studies do not take into account the protective factors (which will be considered later in this review) that are found in starchy food and affect cariogenicity but not acidogenicity. Incubation studies have shown that starches produce similar amounts of acid to sucrose, but over a much longer time period (Beck \& Bibby, 1961).

In summary, the cariogenicity of uncooked starch is very low but this is seldom consumed by humans. Finely ground heat treated starches can cause dental caries but to a much lesser extent than sucrose. There is little evidence to show that cooked staple foods such as rice, potatoes, and bread are cariogenic as consumed by humans. Manufactured foods, in which starch is heat treated and hydrolysed and especially if mixed with sugars, form a potential threat to teeth. The addition of sugars greatly increases the cariogenicity of cooked starches. Less refined starchy foods contain protective factors and it has been suggested that their fibrous nature may aid removal of plaque and food from the mouth, although only from exposed surfaces.

\section{CORN STARCH SWEETENERS AND DENTAL HEALTH}

Corn starch products which include glucose syrups and maltodextrins (glucose polymers) are becoming increasingly available in foods and drinks. Glucose syrups are produced by hydrolysis of corn starch and have a dextrose equivalent (total reducing power expressed as dextrose) $>20$. When a product has a dextrose equivalent $<20$ it is called a maltodextrin (Commerford, 1974). Corn starch degradation products are a mixture of 
mono-, di-, tri-, tetra-, penta-, hexa-, and hepta-saccharides with $13-45 \%$ of saccharides greater than seven in chain length. The monosaccharides, disaccharides and trisaccharides can be readily metabolized by $S$. mutans. Further hydrolysis may be limited to some extent by the time retained in the oral cavity. In theory, because of their relatively long chain length, glucose polymers should be metabolized to a lesser extent than sugars. $S$. mutans is capable of intracellular uptake of longer chain length saccharides (Russell et al. 1992); whether or not this results in a significant production of acid in vivo remains to be determined. Starch consists of glucose units joined together by $\alpha(1-4)$ (straight chain) and $\alpha(1-6)$ (branched chain) links. Amylase is unable to breakdown the $\alpha(1-6)$ linkages or the $\alpha(1-4)$ links adjacent to the branching point, which results in a number of products called 'limit dextrins'. The ability of the oral bacteria to metabolize limit dextrins has also been investigated (Whiting et al. 1993); it has been shown that they are capable of activating the dex B enzyme (EC 3.2.1.70) present in $S$. mutans. The dex B enzyme is capable of breaking down limit dextrins and isomaltosaccharides to maltose and glucose, resulting in the production of further fermentable substrate.

Most studies relating corn syrups to dental health have been carried out by Grenby in the UK. In a study of male subjects participating in the British Antarctic Survey, subjects were given a diet in which all the foods were reformulated with glucose syrups instead of sucrose. After 10-12 weeks subjects exhibited markedly reduced plaque scores, which was not observed for those on sucrose diets (Fry \& Grenby, 1972). The effect on actual caries development was not investigated and there is no strong evidence that the amount of plaque present is related to caries development.

In baboons it has been demonstrated that diets containing $75 \%$ spray-dried glucose syrups produced higher plaque scores after 6 months compared to animals fed a sucrose diet (Grenby, 1971). The ability of spray-dried glucose syrup to cause dental caries has also been tested in rats and has been found not to produce more caries than sugar (Grenby, 1972). However, the form in which glucose syrups are incorporated into the diet appears to influence their cariogenicity. Taken as a $20 \%$ solution, glucose syrups gave rise to a level of dental caries $60 \%$ lower than sucrose in Osborne-Mendel rats (Grenby \& Leer, 1974).

Information on the cariogenic potential of glucose polymers is sparse. A plaque $\mathrm{pH}$ study to compare the acidogenic potential of $10 \%$ solutions of sucrose and glucose polymers showed that glucose polymers caused a decrease in plaque $\mathrm{pH}$, but values obtained for $\mathrm{pH}$ area and maximum $\mathrm{pH}$ decrease were significantly lower than those obtained for sucrose. However, $42 \%$ of subjects obtained minimum pH values below 5.5 (Moynihan et al. 1995a).

Summary. The mode of consumption and the food in which corn starch products are consumed is likely to influence cariogenicity. At present there is insufficient evidence to draw firm conclusions on the effects of corn syrups and glucose polymers on teeth.

\section{ORAL RETENTION OF FOOD AND CARIES RISK}

The extent to which foods tend to be retained in the mouth following consumption will contribute to cariogenicity. Oral clearance is influenced by the components of the food itself, the saliva flow and the action of the tongue, lips and cheeks. In the Vipeholm study, the chocolate group had a smaller increase in caries increment compared to other groups of sugary foods which tended to be sticky. Because of its high fat content, chocolate is cleared from the mouth relatively quickly (Bibby et al. 1951; Brudevold et al. 1990). Edgar et al. (1975) recorded the oral retention times of several sugar- and carbohydratecontaining foods at different time intervals after consumption. Sponge cake, crackers and white bread were shown to have the longest retention times, and, not surprisingly, sugared 
soft drinks and chocolate milk were shown to be cleared most rapidly. Sugar-containing drinks as habitually consumed are, however, in contact with the teeth long enough to cause a significant decrease in plaque $\mathrm{pH}$.

\section{NON-SUGAR SWEETENERS}

Since the Turku study, which showed the benefits to dental health of replacing sugars with the non-sugar sweetener xylitol (Scheinin \& Mäkinen, 1975), the use of non-cariogenic sweeteners in place of sugars has been researched widely. Intense sweeteners (saccharin, aspartame, acesulfame potassium and thaumatin) are not chemically related to sugars and are safe for teeth. Saccharin and aspartame may have anticaries properties, inhibiting bacterial growth and metabolism (Grenby \& Saldanha, 1986; Newbrun, 1990). Saccharin has been shown to inhibit dental caries in rats (Tanzer \& Slee, 1983). Bulk non-sugar sweeteners (sorbitol, mannitol, lactitol, isomalt and lycasin) are chemically related to sugars and are very slowly metabolized by the oral bacteria. However, extensive research has shown that they are non-cariogenic or virtually so (see Grenby, 1991). Xylitol is not metabolized and is a salivary stimulant; however, the possibility of an anti-S. mutans effect of xylitol has yet to be clearly quantified (Bär, 1988). To discuss in full the effects on dental health of non-sugar sweeteners is beyond the scope of this review; however, an interesting account is given by Rugg-Gunn (1993).

\section{MALNUTRITION AND DENTAL CARIES}

Teeth are affected during their formation by nutrition. Nutrient deficiencies can result in defective enamel formation (enamel hypoplasia) which has aesthetic disadvantages and which may increase the susceptibility to dental caries. Malnutrition can also increase the risk of dental caries by affecting the salivary glands so that the flow rate is reduced and the composition of saliva changed (Johansson et al. 1989).

The association between malnutrition and defective enamel formation was first noted by Sweeney et al. (1971) in a study of Guatemalan children; they found that while $43 \%$ of children with second-degree malnutrition had dental hypoplasia, $73 \%$ of those with thirddegree malnutrition were affected. Infante \& Gillespie (1977) found that malnutrition was an aetiological factor in dental hypoplasia which resulted in increased susceptibility to caries. Despite a general consensus that malnutrition increased defective enamel formation, the mechanism for this was uncertain. It was not until 1981 that Nikiforuk \& Fraser showed hypoplasia to be associated with hypocalcaemia, which is a common occurrence in malnutrition due to chronic diarrhoea. In addition to this, evidence also shows that protein deficiency can cause both defects in tooth development (Aponte-Merced \& Navia, 1980) and salivary gland hypoplasia (Menaker \& Navia, 1973). Alvarez et al. (1990) showed that malnutrition delayed tooth eruption, which resulted in a lower caries incidence for a given age due to a shorter time of exposure to cariogenic agents. More recently Alvarez et al. (1995) have found that Peruvian children who were malnourished during the first year of life and who were stunted and wasted had a higher incidence of dental caries at age four than age matched controls, despite a delayed eruption of primary teeth.

While dental caries occurs in affluent communities with a good nutritional status, it is rare in many communities in which malnutrition is widespread. However, when developing countries are exposed to sugars in the diet, the level of caries is greater than expected from experience in Western countries. This observation has led to the suggestion that malnutrition enhances the cariogenic effect of sugars (Enwonwu, 1973; Nikiforuk \& Frazer, 1981; Alvarez \& Navia, 1989). 
In the early half of this century Edward Mellanby was a pioneer in the field of vitamin discovery, and his wife May did much work on the influence of vitamins on the development of teeth. In 1918 she reported that dogs reared on a vitamin $\mathrm{D}$ deficient diet had poorly aligned teeth with hypocalcified enamel (Mellanby, 1918). Mellanby showed that supplementation with fat-soluble vitamins and calcium, during the pre-eruptive development phase of the tooth, resulted in lower initiation and spread of dental caries and more hardening of pre-carious lesions compared with controls (Mellanby \& Pattison, 1928). An improvement in British children's teeth was observed between 1929 and 1943, which Mellanby attributed to the introduction of cheap milk in 1934 and the wartime food policy which led to an increased intake of calcium and vitamin D (Mellanby \& Coumoulos, 1944). Mellanby added the fact that dental caries was rare in the tropics, where there was plenty of sunshine, to her argument that vitamin D played a role in caries susceptibility. More recently studies in Alberta, Canada, have shown that installing full spectrum lighting in classrooms resulted in a lower caries increment in the pupils over a two-year period, compared to children classed in rooms with conventional lighting (Hargreaves \& Thompson, 1989).

In summary, in poorly nourished communities where sugar is available, malnutrition may increase caries risk by causing defective enamel development and salivary gland atrophy. Defective enamel appears to stem from hypocalcaemia associated with malnutrition and is also caused by vitamin $\mathrm{D}$ deficiency.

\section{DIETARY CAUSES OF DENTAL EROSION}

Dental erosion is not generally perceived as a public health problem despite concern amongst dentists for the past 20 years that it is increasing (Levine, 1973; Rugg-Gunn, 1993). Twenty-eight \% of $3 \frac{1}{2}-4 \frac{1}{2}$-year-old children in the National Diet and Nutrition Survey (Office of Population Censuses \& Surveys, 1995), and 32\% of 14-year-olds in the National Child Dental Health Survey (O'Brien, 1994) had evidence of dental erosion.

Diet has been recognized as an important cause of dental erosion for over a century (Darby, 1892; Miller, 1907). Dietary acids, the erosive components of food, differ in erosive capacity. Citric, malic and tartaric acids are the most erosive due to their acidic nature and because at higher pH they chelate calcium (McClure \& Ruzicka, 1946; Meurman et al. 1987). Carbonic acid is the least erosive (Jarvinen et al. 1991). Phosphoric acid is very erosive, especially at low pH (Imfeld, 1983).

The majority of published data on dental erosion has been as case reports. Erosion has been reported in patients who consume acidic drinks on a daily basis (Asher \& Reed, 1987), in infants consuming juices from comforters (Smith \& Shaw, 1987) and in citrus fruit pickers (Pickerill, 1912). In the past, dental erosion arose largely as the result of unusual dietary practices. Fuller \& Johnson (1977) reported a case of extensive erosion attributed to frequent sucking of limes at tequila parties, and one of a 23-year-old woman who had sucked lemons since childhood. Giunta (1983) reported a case of erosion arising from chewing of ascorbic acid tablets three times a day over a period of 3 years. Other cases have been linked with excessive consumption of cola, both sugared and sugar-free (Lewis \& Smith, 1973; Guggenheimer \& Schneider, 1980), consumption of lemon tea at night (Lewis \& Smith, 1973) and weight-reducing diets containing two or three grapefruits a day (Reuter, 1978). Consumption of carbonated beverages is increasing $-24 \%$ of preschool children consume such beverages daily (Office of Population Censuses \& Surveys, 1995). Recent evidence suggests a relationship between severity of dental erosion and the frequency of carbonated beverage and fruit based beverage consumption (Millward et al. 1994). 
In summary, the prevalence of erosion is increasing and it is no longer limited to unusual dietary practices. The increasing trend to frequent consumption of acidic beverages is likely to be a major aetiological factor.

\section{THE RELATIONSHIP BETWEEN TOOTH LOSS, DIET AND NUTRITIONAL STATUS}

Tooth loss is of concern because teeth are important for consumption of a varied diet, and their loss has been shown to have detrimental effects on food choice, nutrient intake and health.

Despite a downward trend in the proportion of the adult population who are edentulous, the 1991 General Household Survey reported that $16 \%$ of British adults had no teeth. Recent data show that in a representative sample of people from the north east of England, $41 \%$ of adults over 45 years of age were edentulous (Walls \& Donachie, 1995).

Geissler \& Bates (1984) reviewed the nutritional consequences of tooth loss and were critical of the methods employed in many studies. Methods to assess dietary intake have often been poor and many studies have failed to control for confounding factors.

\section{THE INFLUENCE OF TOOTH LOSS ON THE DIGESTION OF FOODS}

The influence of mastication on digestion was investigated by Farrell in 1956. Subjects swallowed mesh bags containing prechewed and unchewed samples of food and residues were collected from faeces and weighed. Foods which left large undigested residues when unchewed included meat, fried potato, boiled potato, peas and carrots. Foods which were completely digested even when not chewed were fish, rice, eggs, cheese and white bread. Mastication greatly increases the digestibility of some foods. The subjects in Farrell's studies were young and ability to digest is reduced with age, making mastication of food more important for maximum digestion. It is therefore paradoxical that the elderly with reduced digestive function are also likely to be those with lesser masticatory ability.

\section{THE INFLUENCE OF TOOTH LOSS ON THE CHOICE OF FOODS}

If mastication is difficult, the selection of foods in the diet is likely to be altered. Data from a number of studies suggest that the extent of dental invalidity is reflected in the degree of difficulty experienced in eating certain foods. Osterberg \& Steen (1982), in a study of 70year-old Finnish males, found that Eichner's index (based on the number of dental contacts in the premolar and molar region of the jaws) was inversely related to the intake of chicken, vegetables, bacon and apples. Mäkila $(1968,1969 a, b)$ studied the effects of complete dentures on food choice, and showed that soft foods such as porridge were eaten more frequently by those without teeth and hard and fibrous foods less frequently. Hard foods included fruit, raw vegetables, cheese and meat. Heath (1972), in a study of housebound pensioners, asked subjects whether they ate a range of foods from soft to hard, and found that as dental state deteriorated, foods such as nuts, raw celery and hard biscuits were progressively excluded from the diet. The study was too small to control for age, gender and other social variables. In a study of 54 full denture wearers (Bergman \& Carlsson, 1972), 25 foods were ranked according to difficulty to chew. Pastries, cookies and potatoes were the easiest to chew, whereas carrots, caramel and apples were the most difficult. Sato et al. (1989), in a study of 110 full denture wearers who classified 100 foods according to the ease with which they could chew them, found that apples and chewing gum were amongst the 
foods most difficult to chew and boiled fish and boiled potato were amongst the food easiest to chew.

\section{THE INFLUENCE OF TOOTH LOSS ON THE INTAKE OF NUTRIENTS AND NUTRITIONAL STATUS}

Despite substantial data on the effect of tooth loss on food selection, there are very few studies which, using valid and reliable methods, have looked at the effect of tooth loss on nutrient intake and nutritional status. In the study by Osterberg \& Steen (1982) of a 70year-old Finnish population, a significantly greater proportion of dentally invalid subjects had intakes of one or more nutrients below the level which the authors defined as adequate. Mäkila $(1969 a, b)$ reported lower serum concentrations of vitamin C, E, pantothenic acid and iron in edentulous compared to dentate adults, though this does not necessarily imply deficiencies. Geissler \& Bates (1984) concluded that the specific nutrients of which intake is likely to be reduced by dental invalidity are vitamin $\mathrm{C}$, folic acid, iron and non-starch polysaccharides (NSP). Despite reports of avoidance of fibrous foods, few data exist of NSP intake by edentulous subjects. Studies in Canada (Brodeur \& Laurin, 1993) have shown that edentulous persons with low masticatory performance use significantly more laxatives and antacids compared to edentulous subjects with superior masticatory performance. Subjects with low masticatory performance also ate high fibre foods less frequently. The only data from the UK are from a study of patients attending Newcastle Dental School (Moynihan et al. 1994). In this study wearers of full dentures, age 40-60 years, had a significantly lower intake of NSP $(10.4 \mathrm{~g} / \mathrm{d})$ compared to dentate adults $(15 \cdot 1 \mathrm{~g} / \mathrm{d})$ of the same age group (matched for social class). Furthermore NSP intake of $56 \%$ of the edentulous group was below the level $(<12 \mathrm{~g} / \mathrm{d})$ associated with low faecal weight and gastrointestinal disorders (Department of Health, 1991). It could, however, be argued that the relationship is not causal and simply reflects a poorer quality of diet in those who become edentulous. Further studies of the effect of tooth loss on nutrition and health, for example intake of NSP and bowel health, are needed.

\section{THE BENEFITS OF DENTAL PROSTHESES ON CHEWING ABILITY, FOOD CHOICE AND NUTRITIONAL STATUS}

Optimizing full dentures has been shown to improve chewing efficiency (Gunne \& Wall, 1985). In the study of Heath (1972), persons with better fitting dentures were able to chew twice as many hard foods as persons with poor fitting dentures. Bergman \& Carlsson (1972) also found a strong correlation between the fit of dentures and chewing efficiency. However, Meehan et al. (1995) reported no benefit one year from fitting dentures in terms of dietary selection. Fixed dental prostheses (tissue integrated prostheses) have been shown to improve chewing ability to a greater extent than optimizing full dentures (Haraldson \& Carlsson, 1979; Lindqvist \& Carlsson, 1985) and to result in increased intake of fruit and crispbread (Sandstrom \& Lindqvist, 1987). The effect of prosthetic rehabilitation on nutrient intake and health has not been investigated.

In summary, lack of teeth has a marked effect on chewing ability and has been shown to restrict the consumption of several foods. Information on the effects of tooth loss on nutritional status and health is lacking, although there is some suggestion of a low intake of NSP and a higher use of laxatives by the edentulous. Optimizing dentures aids chewing ability but fixed prostheses have been shown to have the most marked effect on masticatory efficiency and food choice. There is no information on the effect of prosthetic rehabilitation 
on nutrient intake, status or health and there is a definite need for well conducted studies in the field of tooth loss and nutrition.

\section{CONCLUSIONS}

Despite improvements in the nation's dental health there still exists a number of key areas of current relevance and concern with respect to diet and dental health. Edentulousness is still a sizeable problem in many areas and its effects on nutritional status and health have not been clearly defined. The possible involvement of free radical damage and the availability of dietary antioxidants in the aetiology of periodontal disease need to be evaluated. Dental caries continues to be the predominant cause of tooth loss in the United Kingdom; it is produced by the relationship between sugars in diet, the presence of plaque, saliva flow, availability of fluoride and the strength of the teeth. As children in developed countries do not in general show signs of malnutrition, and the rise of fluoride toothpaste is widespread, the obvious way forward to continue the downward trend in caries occurrence is by dietary intervention to control sugars eating habits. Such advice should be given in line with dietary advice for overall health.

\section{REFERENCES}

Afonsky, D. (1951). Some observations on dental caries in central China. Journal of Dental Research 30, 53-61. Akpata, E. S. (1979). Patterns of dental caries in urban Nigerians. Caries Research 13, 241-249.

Albrecht, M., Bánóczy, J. \& Tamas, G. (1988). Dental and oral symptoms of diabetes mellitus. Community Dentistry and Oral Epidemiology 16, 378-380.

Altman, L. C., Baker, C., Fleckman, P., Luchtel, D. \& Oda, D. (1992). Neutrophil-mediated damage to human gingival epithelial cells. Journal of Periodontal Research 27, 70-79.

Alvarez, J. O., Caceda, J. \& Aguayo, H. (1995). Early childhood caries and nutritional status. Journal of Dental Research 74, 468 (abstract).

Alvarez, J. O., Eguren, J. C., Caceda, J. \& Navia, J. M. (1990). The effect of nutritional status on the age distribution of dental caries in the primary teeth. Journal of Dental Research 69, 1564-1566.

Alvarez, J. O. \& Navia, J. M. (1989). Nutritional status, tooth eruption, and dental caries: a review. American Journal of Clinical Nutrition 49, 417-426.

Anaise, J. Z. (1978). Prevalence of dental caries amongst workers in the sweets industry in Israel. Community Dentistry and Oral Epidemiology 6, 286-289.

Aponte-Merced, L. \& Navia, J. M. (1980). Pre-eruptive protein-energy malnutrition and acid solubility of rat molar enamel surfaces. Archives of Oral Biology 25, 701-705.

Araujo, D. R., Velasco, L. F., Del Bel Cury, A. A., Maltz, M., Aranjo, F. B. \& Cury, J. A. (1995). An in situ evaluation of cariogenic potential of human breast milk. Journal of Dental Research 74, 48 (abstr. no. 294).

Asher, C. \& Reed, M. J. F. (1987). Early enamel erosion in children associated with the excessive consumption of citric acid. British Dental Journal 162, 384-387.

Ashley, F. P., Naylor, M. N. \& Emslie, R. D. (1974). Clinical testing of dicalcium phosphate supplemented sweets. British Dental Journal 136, 361-366; 418-423.

Åsman, B., Wijkander, P. \& Hjerpe, A. (1994). Reduction of collagen degradation in experimental granulation tissue by vitamin $\mathrm{E}$ and selenium. Journal of Clinical Periodontology 21, 45-47.

Aurer-Kozelj, J., Kralj-Klobučar, N., Buzina, R. \& Bačić, M. (1982). The effect of ascorbic acid supplementation on periodontal tissue ultrastructure in subjects with progressive periodontitis. International Journal of Vitamin and Nutrition Research 52, 333-341.

Averill, H. M., Freire, P. S. \& Bibby, B. G. (1966). The effect of dietary phosphate supplements on dental caries incidence in tropical Brazil. Archives of Oral Biology 11, 315-322.

Bánóczy, J., Zimmermann, P., Hadas, E., Pinter, A. \& Bruszt, V. (1985). Effect of fluoridated milk on caries : five year results. Journal of the Royal Society of Health 105, 99-103.

Bánóczy, J., Zimmermann, P., Pinter, A., Hadas, É. \& Bruszt, V. (1983). Effect of fluoridated milk on caries: three year results. Community Dentistry and Oral Epidemiology 11, 81-85.

Bär, A. (1988). Caries prevention with xylitol: a review of the scientific evidence. In Sociological and Medical Aspects of Nutrition (World Review of Nutrition and Dietetics 55), pp. 183-209 [G. H. Bourne, editor]. Basel: Karger.

Barron, E. G. \& Lewis, J. F. (1968). Effect of a school's naturally fluoridated water on the prevalence of carious lesions. Journal of Public Health Dentistry 28, 167-172. 
Baume, L. J. (1969). Caries prevalence and caries intensity among 12,344 schoolchildren of French Polynesia. Archives of Oral Biology 14, 181-205.

Bavetta, L. A. \& McClure, F. J. (1957). Protein factors and experimental rat caries. Journal of Nutrition 63, 107-117.

Beck, D. J. \& Bibby, B. G. (1961). Acid production during the fermentation of starches by saliva. Journal of Dental Research 40, 486-491.

Becks, H., Wainwright, W. W. \& Morgan, A. F. (1943). Comparative study of oral changes in dogs due to deficiencies of pantothenic acid, nicotinic acid and unknowns of the B vitamin complex. American Journal of Orthodontics \& Oral Surgery 29, 183-207.

Beighton, D. \& Hayday, H. (1984). The establishment of the bacterium Streptococcus mutans in dental plaque and the induction of caries in macaque monkeys (Macaca fascicularis) fed a diet containing cooked wheat flour. Archives of Oral Biology 29, 369-372.

Bergman, B. \& Carlsson, G. E. (1972). Review of 54 complete denture wearers: patients' opinions one year after treatment. Acta Odontologica Scandinavica 30, 399-414.

Bernick, S. M., Cohen, D. W., Baker, L. \& Laster, L. (1975). Dental disease in children with diabetes mellitus. Journal of Periodontology 46, 241-245.

Bibby, B. G., Goldberg, H. J. V. \& Chen, E. (1951). Evaluation of caries-producing potentialities of various foods. Journal of the American Dental Association 42, 491-509.

Bibby, B. G. \& Krobicka, A. (1984). An in vitro method for making repeated pH measurements on human dental plaque. Journal of Dental Research 63, 906-909.

Bibby, B. G., Mundorff, S. A. \& Huang, C. T. (1983). Enamel demineralization tests with some standard foods and candies. Journal of Dental Research $62,885-888$

Bibby, B. G., Mundorff, S. A., Zero, D. T. \& Almekinder, K. J. (1986). Oral food clearance and the pH of plaque and saliva. Journal of the American Dental Association 112, 333-337.

Bowen, W. H. (1972). The cariostatic effect of calcium glycerophosphate in monkeys. Caries Research 6, 43-51.

Bowen, W. H., Amsbaugh, S. M., Monnell-Torrens, S., Brunelle, J., Kuzmiak-Jones, H. \& Cole, M. F. (1980). A method to assess cariogenic potential of foodstuffs. Journal of the American Dental Association 100, 677-681.

Bowen, W. H., Pearson, S. K., van Wuyckhuyse, B. C. \& Tabak, L. A. (1991). Influence of milk, lactose-reduced milk, and lactose on caries in desalivated rats. Caries Research 25, 283-286.

Bradford, E. W. \& Crabb, H. S. M. (1961). Carbohydrate restriction and caries incidence: a pilot study. British Dental Journal 111, 273-279.

Bradford, E. W. \& Crabb, H. S. M. (1963). Carbohydrates and the incidence of caries in the deciduous dentition. In Advances in Fluorine Research and Dental Caries Prevention (1962 Congress), vol. 1, pp. 319-323 [J. L. Hardwick, J.-L. Dustin and H. R. Held, editors]. Oxford: Pergamon Press.

Brodeur, J. M. \& Laurin, D. (1993). Nutrient intake and gastrointestinal disorders related to masticatory performance in the edentulous elderly. Journal of Prosthetic Dentistry 70, 468-473.

Brudevold, F., Attarzadeh, F., Tehrani, A., van Houte, J. \& Russo, J. (1984). Development of a new intraoral demineralization test. Caries Research 18, 421-429.

Brudevold, F., Goulet, D., Tehrani, A., Attarzadeh, F. \& van Houte, J. (1985). Intraoral demineralization and maltose clearance from wheat starch. Caries Research 19, 136-144.

Brudevold, F., Kashket, S. \& Kent, R. L. (1990). The effect of sucrose and fat in cookies on salivation and oral retention in humans. Journal of Dental Research 69, 1278-1282.

Burrill, D. Y. (1942). Relationship of blood plasma vitamin C level to gingival and periodontal disease. Journal of Dental Research 21, 353-363.

Burt, B. A., Eklund, S. A., Morgan, K. J., Larkin, F. E., Guire, K. E., Brown, L. O. \& Weintraub, J. A. (1988). The effects of sugars intake and frequency of ingestion on dental caries increment in a three-year longitudinal study. Journal of Dental Research 67, 1422-1429.

Caldwell, R. C. (1970). Physical properties of foods and their caries producing potential. Journal of Dental Research 49, 1293-1298.

Carlsson, J. \& Egelberg, J. (1965). Effect of diet on early plaque formation in man. Odontologisk Revy 16, 112-125.

Cerna, H., Fiala, B., Fingerova, H., Pohanka, E. \& Szwarcon, A. (1984). Contribution to indication of total therapy with vitamin $\mathrm{E}$ in chronic periodontal disease (pilot study). Acta Universitatis Palackianae Olomucensis Facultatis Medicae 107, 167-170.

Cohen, M. M. (1955). The effect of large doses of ascorbic acid on gingival tissues at puberty. Journal of Dental Research 34, 750-751.

Colman, G., Bowen, W. H. \& Cole, M. F. (1977). Effects of sucrose, fructose and a mixture of glucose and fructose on the incidence of dental caries in monkeys (Macaca fascicularis). British Dental Journal 142, $217-223$.

Commerford, J. D. (1974). Corn sweetener industry. In Sweeteners (symposium) [I. E. Inglett, editor]. Westport, CT: AVI.

Cowan, A. (1976). The influence of vitamin C on the periodontal membrane space - a radiographic study. Irish Journal of Medical Science 145, 273-284.

Dachi, S. F., Saxe, S. R. \& Bohannan, H. M. (1966). The failure of short-term vitamin supplementation to reduce sulcus depth. Journal of Periodontology 37, 221-223.

Darby, E. T. (1892). Dental erosion and gouty diathesis, are they related? Dental Cosmos 34, 629-640. 
Dean, H. T. (1936). Chronic endemic dental fluorosis (mottled enamel). Journal of the American Medical Association 107, 1269-1272.

Dean, H. T., Arnold, F. A. \& Elvove, E. (1942). Domestic water and dental caries. 5. Additional studies of the relation of fluoride domestic waters to dental caries prevalence in 4425 white children, age 12-14 years, of 13 cities of 4 states. Public Health Reports 57, 1155-1179.

de Crousaz, P., Marthaler, T., Weisner, V., Bandi, A., Steiner, M., Roberts, A. \& Meyer, R. (1985). Caries prevalence in children after 12 years of salt fluoridation in a Canton of Switzerland. Schweizerische Monatsschrift für Zahnmedizin 95, 805-815.

Department of Health (1991). Dietary Reference Values for Food Energy and Nutrients for the United Kingdom. Report on Health and Social Subjects no. 41. London: HMSO.

Department of Health (1994a). An Oral Health Strategy for England. London: HMSO.

Department of Health (1994b). Weaning and the Weaning Diet. Report on Health and Social Subjects no. 45. London: HMSO.

Department of Health (1994c). Nutritional Aspects of Cardiovascular Disease. Report on Health and Social Subjects no. 46. London: HMSO.

Driesen, S. \& Spies, T. D. (1952). The incidence of dental caries in habitual sugar cane chewers. Journal of the American Dental Association 45, 193-200.

Drummer, P. M. H., Oliver, S. J., Hicks, R., Kingdon, A., Kingdon, R., Addy, M. \& Shaw, W. C. (1990). Factors influencing the caries experience of a group of children at the ages of 11-12 and 15-16 years; results of an ongoing epidemiological survey. Journal of Dentistry 18, 37-48.

Duff, E. J. (1981). Total and ionic fluoride in milk. Caries Research 15, 406-408.

Edgar, W. M. (1985). Prediction of the cariogenicity of various foods. International Dental Journal 35, 190-194.

Edgar, W. M., Bibby, B. G., Mundorff, S. \& Rowley, J. (1975). Acid production in plaques after eating snacks: modifying factors in foods. Journal of the American Dental Association 90, 418-425.

Edgar, W. M. \& Geddes, D. A. M. (1990). Chewing gum and dental health: a review. British Dental Journal 168, 173-177.

Enwonwu, C. O. (1973). Influence of socio-economic conditions on dental development in Nigerian children. Archives of Oral Biology 18, 95-107.

Farrell, J. H. (1956). The effect of mastication on the digestion of food. British Dental Journal 100, 149-155.

Finn, S. B., Frew, R. A., Leibowitz, R., Morse, W., Manson-Hing, L. \& Brunelle, J. (1978). The effect of sodium trimetaphosphate (TMP) as a chewing gum additive on caries increments in children. Journal of the American Dental Association 96, 651-655.

Firestone, A. R., Schmid, R. \& Mühlemann, H. R. (1982). Cariogenic effects of cooked wheat starch alone or with sucrose and frequency-controlled feedings in rats. Archives of Oral Biology 27, 759-763.

Firestone, A. R., Schmid, R. \& Mühlemann, H. R. (1984). Effect of the length and number of intervals between meals on caries in rats. Caries Research 18, 128-133.

Fisher, F. J. (1968). A field survey of dental caries, periodontal disease and enamel defects in Tristan da Cunha. 2. Methods and results. British Dental Journal 125, 447-453.

Fosdick, L. S., Campaigne, E. E. \& Fancher, O. E. (1941). Rate of acid formation in carious areas: the etiology of dental caries. Illinois Dental Journal 10, 85-95.

Frencken, J. E., Rugarabaum, P. \& Mulder, J. (1989). The effect of sugar cane chewing on the development of dental caries. Journal of Dental Research 68, 1102-1104.

Frostell, G. (1972). Effect of cooked starch solution on the pH of dental plaque. Swedish Dental Journal 65, 161-165.

Frostell, G. (1973). Effects of mouth rinses with sucrose, glucose, fructose, lactose, sorbitol and Lycasin on the pH of dental plaque. Odontologisk Revy 24, 217-226.

Fry, A. J. \& Grenby, T. H. (1972). The effects of reduced sucrose intake on the formation and composition of dental plaque in a group of men in the Antarctic. Archives of Oral Biology 17, 873-882.

Fuller, J. L. \& Johnson, W. W. (1977). Citric acid consumption and the human dentition. Journal of the American Dental Association 95, 80-84.

Gaengler, P., Pfister, W., Sproessig, M. \& Mirgorod, M. (1986). The effects of carbohydrate-reduced diet on development of gingivitis. Clinical Preventive Dentistry 8, 17-23.

Gedalia, I., Galon, H., Rennert, A., Biderco, I. \& Mohr, I. (1981). Effect of fluoridated citrus beverages on dental caries and on fluoride concentration in the surface enamel of children's teeth. Caries Research 15, 103-108.

Geissler, C. A. \& Bates, J. F. (1984). The nutritional effects of tooth loss. American Journal of Clinical Nutrition $39,478489$.

Giunta, J. L. (1983). Dental erosion resulting from chewable vitamin C tablets. Journal of the American Dental Association 107, 253-256.

Glass, R. L. (1982). The first international conference on the declining prevalence of dental caries. Introduction. Journal of Dental Research 61, 1301-1304.

Glass, R. L. \& Hayden, J. (1966). Dental caries in Seventh Day Adventist children. Journal of Dentistry for Children 33, 22-23.

Glickmann, I. (1979). Nutritional influences on the periodontum. In Glickman's Clinical Periodontology, 5th edn, pp. 489-505 [F. A. Carranza, editor]. Philadelphia, PA: Saunders. 
Goodson, J. M. \& Bowles, D. (1973). The effect of $\alpha$-tocopherol on sulcus fluid flow in periodontal disease. Journal of Dental Research 52, 217 (Abstr.).

Graf, H. (1970). The glycolytic activity of plaque and its relation to hard tissues pathology; recent findings from intraoral pH telemetry research. International Dental Journal 20, 426-435.

Granath, L.-E., Rootzen, H., Liljegren, E., Holst, K. \& Köhler, L. (1978). Variation in caries prevalence related to combinations of dietary and oral hygiene habits and chewing fluoride tablets in 4-year-old children. Caries Research 12, 83-92.

Green, R. M. \& Hartles, R. L. (1967). The effect of uncooked and roll-dried maize starch, alone and mixed in equal quantity with sucrose, on dental caries in the albino rat. British Journal of Nutrition 21, 225-230.

Green, R. M. \& Hartles, R. L. (1970). The effects of diets containing varying percentages of sucrose and maize starch on caries in the albino rat. Caries Research 4, 188-192.

Grenby, T. H. (1965). The influence of cooked and raw wheat starch on dental caries in the rat. Archives of Oral Biology 10, 433-438.

Grenby, T. H. (1967). Investigation in experimental animals on the cariogenicity of diets containing sucrose and/or starch. Caries Research 1, 208-221.

Grenby, T. H. (1971). Dental plaque studies on baboons fed on diets containing different carbohydrates. Archives of Oral Biology 16, 631-638.

Grenby, T. H. (1972). The effect of glucose syrup on dental caries in the rat. Caries Research 6, 52-59.

Grenby, T. H. (1973). Trials of three organic phosphorus-containing compounds as protective agents against dental caries in rats. Journal of Dental Research 52, $454-461$.

Grenby, T. H. (1990). Snack foods and dental caries. Investigations using laboratory animals. British Dental Journal 168, 353-361.

Grenby, T. H. (1991). Update on low-calorie sweeteners to benefit dental health. International Dental Journal 41, 217-224.

Grenby, T. H. \& Bull, J. M. (1975). Protection against dental caries in rats by glycerophosphates or calcium salts or mixtures of both. Archives of Oral Biology 20, 717-724.

Grenby, T. H. \& Leer, C. J. (1974). Reduction in 'smooth surface' caries and fat accumulation in rats when sucrose in drinking water is replaced by glucose syrup. Caries Research 8, 368-372.

Grenby, T. H. \& Paterson, F. M. (1972). Effect of sweet biscuits on the incidence of dental caries in rats. British Journal of Nutrition 27, 195-199.

Grenby, T. H. \& Saldanha, M. G. (1986). Studies of the inhibitory action of intense sweeteners on oral microorganisms relating to dental health. Caries Research 20, 7-16.

Guggenheim, B., König, K. G., Herzog, E. \& Mühlemann, H. R. (1966). The cariogenicity of different dietary carbohydrates tested on rats in relative gnotobiosis with a Streptococcus producing extracellular polysaccharide. Helvetica Odontologica Acta 10, 101-113.

Guggenheimer, J. \& Schneider, L. G. (1980). Tooth erosion associated with excessive use of an artificially sweetened Cola beverage. Journal of Preventive Dentistry 6, 261-262.

Gunne, H. S. \& Wall, A. K. (1985). The effect of new complete dentures on mastication and dietary intake. Acta Odontologica Scandinavica 43, 257-268.

Gustafsson, B. E., Quensel, C. E., Lanke, L. S., Lundqvist, C., Grahnén, H., Bonow, B. E. \& Krasse, B. (1954). The Vipeholm dental caries study. The effect of different levels of carbohydrate intake on caries activity in 436 individuals observed for five years. Acta Odontologica Scandinavica 11, 232-364.

Hackett, A. F., Rugg-Gunn, A. J., Murray, J. J. \& Roberts, G. J. (1984). Can breast feeding cause dental caries? Human Nutrition: Applied Nutrition 38A, 23-28.

Hankin, J. H., Chung, C. S. \& Kau, M. C. W. (1973). Genetic and epidemiologic studies of oral characteristics in Hawaii's school-children: diet patterns and caries prevalence. Journal of Dental Research 52, 1079-1086.

Haraldson, T. \& Carlsson, G. E. (1979). Chewing efficiency in patients with osseointegrated oral implant bridges. Swedish Dental Journal 3, 183-91.

Hargreaves, J. A. \& Thompson, G. W. (1989). Ultra-violet light and dental caries in children. Caries Research 23, 389-392.

Harper, D. S., Gray, R., Lenke, J. W. \& Hefferren, J. J. (1985). Measurement of human plaque acidity; comparison of interdental touch and indwelling electrodes. Caries Research 19, 536-546.

Harris, R. (1963). Biology of the children of Hopewood House, Bowral, Australia. 4. Observations on dental caries experience extending over 5 years (1957-61). Journal of Dental Research 42, 1387-1399.

Hausen, H., Heinomen, O. P. \& Paunio, I. (1981). Modification of occurrence of caries in children by toothbrushing and sugar exposure in fluoridated and non-fluoridated area. Community Dentistry and Oral Epidemiology 9, 103-107.

Heath, M. R. (1972). Dietary selection by elderly persons, related to dental state. British Dental Journal 132, $145-148$

Hefti, A. \& Schmid, R. (1979). Effect on caries incidence in rats of increasing dietary sucrose levels. Caries Research 13, 298-300.

Heifetz, S. B., Horowitz, H. S. \& Brunelle, J. A. (1983). Effect of school water fluoridation on dental caries: results in Seagrove, NC, after 12 years. Journal of the American Dental Association 106, 334-337.

Henrikson, P. A. (1968). Periodontal disease and calcium deficiency. An experimental study in the dog. Acta Odontologica Scandinavica 26, Suppl. 50. 
Higham, S. M. \& Edgar, W. M. (1989). Effects of Parafilm and cheese chewing on human dental plaque pH and metabolism. Caries Research 23, 42-48.

Hodges, R. E., Hood, J., Canham, J. E., Sauberlich, H. E. \& Baker, E. M. (1971). Clinical manifestations of ascorbic acid deficiency in man. American Journal of Clinical Nutrition 24, 432-443.

Holloway, P. J., Shaw, J. H. \& Sweeney, E. A. (1961). Effects of carious sucrose: casein ratios in purified diets on the teeth and supporting structures of rats. Archives of Oral Biology 3, 185-200.

Holt, R. D., Joels, D., Bulman, J. \& Maddick, I. H. (1988). A third study of caries in preschool aged children in Camden. British Dental Journal 165, 87-91.

Horowitz, H. S., Heifetz, S. B. \& Law, F. E. (1972). Effect of school water fluoridation on dental caries; final results in Elk Lake, PA after 12 years. Journal of the American Dental Association 84, 832-838.

Horowitz, H. S., Heifetz, S. B., Law, F. E. \& Driscoll, W. S. (1968). School fluoridation studies in Elk Lake, Pennsylvania, and Pike County, Kentucky - results after eight years. American Journal of Public Health 58, 2240-2250.

Huang, C. T., Little, M. F. \& Johnson, R. (1981). Influence of carbohydrates on in vitro lesion production. Caries Research 15, 54-59.

Huxley, H. G. (1971). The cariogenicity of various percentages of dietary sucrose and glucose in experimental animals. New Zealand Dental Journal 67, 85-98.

Huxley, H. G. (1977). The cariogenicity of dietary sucrose at various levels in two strains of rat under unrestricted and controlled frequency feeding conditions. Caries Research 11, 237-242.

Imfeld, T. (1977). Evaluation of the cariogenicity of confectionery by intraoral wire telemetry. Schweizerische Monatsschrift für Zahnheilkunde 87, 437-464

Imfeld, T. N. (1983). Identification of Low Caries Risk Dietary Components, pp. 153-155; 165-174. Basel: Karger.

Imfeld, T., Hirsch, R. S. \& Mühlemann, H. R. (1978). Telemetric recordings of interdental plaque pH during different meal patterns. British Dental Journal 144, $40-45$.

Infante, P. F. \& Gillespie, G. M. (1977). Enamel hypoplasia in relation to caries in Guatemalan children. Journal of Dental Research 56, 493-498.

Jacobsen, J. (1979). Recent reorganisation of the public health service in Greenland in favour of caries prevention. Community Dentistry and Oral Epidemiology 7, 75-81.

Jalil, R. A., Cornick, D. E. R. \& Waite, I. M. (1983). Effect of variation in dietary sucrose intake on plaque removal by mechanical means. Journal of Clinical Periodontology 10, 389-398.

Jarvinen, V. K., Rytomaa, I. I. \& Heinonen, O. P. (1991). Risk factors in dental erosion. Journal of Dental Research 70, 942-947.

Jenkins, G. N. (1978). The Physiology and Biochemistry of the Mouth, 4th edn. Oxford: Blackwell.

Jenkins, G. N. \& Ferguson, D. B. (1966). Milk and dental caries. British Dental Journal 120, $472-477$.

Jenkins, G. N. \& Hargreaves, J. A. (1989). Effect of eating cheese on Ca and P concentrations of whole mouth saliva and plaque. Caries Research 23, 159-164.

Jenkins, G. N. \& Smales, F. C. (1966). The potential importance in caries prevention of solubility-reducing and anti-bacterial factors in unrefined plant products. Archives of Oral Biology 11, 599. 608.

Jensen, M. E., Hartander, S. K. \& Schachtele, C. F. (1984). Evaluation of the acidogenic and antacid properties of cheeses by telemetric monitoring of human dental plaque pH. In Foods, Nutrition and Health, vol. 4, pp. 31-48. Chicago, IL: American Dental Association.

Jensen, M. E. \& Welfel, J. S. (1990). Effects of processed cheese on human plaque pH and demineralization and remineralization. American Journal of Dentistry 3, 217-323.

Johansson, I., Lumikari, M. \& Ericson, T. (1989). Effect of moderate vitamin A deficiency on saliva secretion rate and some salivary glycoproteins in adult rat. Scandinavian Journal of Dental Research 97, 263-267.

Katayama, T., Nagagawa, E., Honda, O., Tani, H., Okado, S. \& Suzuki, S. (1979). Incidence and distribution of Strep. mutans in plaque from confectionery workers. Journal of Dental Research $\mathbf{5 8}$, (Special issue D) 2251 (Abstr. 11).

King, J. D. (1940). Dental Disease in the Island of Lewis. MRC Special Report Series no. 241. London: HMSO.

Kleemola-Kujala, E. \& Rasanen, L. (1979). Dietary pattern of Finnish children with low and high caries experience. Community Dentistry and Oral Epidemiology 7, 199-205.

Kleemola-Kujala, E. \& Rasanen, L. (1982). Relationship of oral hygiene and sugar consumption to risk of caries in children. Community Dentistry and Oral Epidemiology 10, 224-233.

König, K. G. (1966). Möglichkeiten der Kariesprophylaxe beim Menschen und ihre Untersuchung im Kurzfristigen Rattenexperiment. Bern: Hans Huber.

König, K. G. (1993). The role of fluoride toothpastes in a caries preventive strategy. In Efficacy of Caries Preventive Strategies, pp. 23-28. Caries Research 27, Supplement.

König, K. G., Schmid, P. \& Schmid, R. (1968). An apparatus for frequency-controlled feeding of small rodents and its use in dental caries experiments. Archives of Oral Biology 13, 13-26.

Koulourides, T., Bodden, R., Keller, S., Manson-Hing, L. L., Lastra, J. \& Housch, T. (1976). Cariogenicity of nine sugars tested with an intraoral device in man. Caries Research 10, 427-441.

Kristofferson, K., Axelsson, P., Birkhed, D. \& Bratthall, D. (1986). Caries prevalence, salivary Streptococcus mutans and dietary scores in 13-year-old Swedish schoolchildren. Community Dentistry and Oral Epidemiology 14, 202-205. 
Kunzel, W., Borroto, R. C., Lanier, S. \& Soto, F. (1973). [Effect of habitual sugarcane chewing on the incidence of caries and periodontal disease in Cuban sugarcane workers.] Deutsche Stomatologie 23, 554-561.

Leggett, B. J., Garbee, W. H., Gardiner, J. F. \& Lancaster, D. M. (1987). The effect of fluoridated chocolate milk on caries incidence in elementary schoolchildren; two and three year studies. Journal of Dentistry for Children $54,18-21$.

Levine, R. S. (1973). Fruit juice erosion - an increasing danger? Journal of Dentistry 2, 85-88.

Levine, R. S. (1991). Fluoride and caries prevention. 1. Scientific rationale. Dental Update (April) $105-110$.

Lewis, K. J. \& Smith, B. G. N. (1973). The relationship of erosion and attrition in excessive tooth tissue loss. British Dental Journal 135, $400-404$.

Lilienthal, B. (1977). Phosphates and Dental Caries. Basel: Karger.

Lilienthal, B., Bush, E., Buckmaster, M., Gregory, G., Gagolski, J., Smythe, B. M., Curtin, J. H. \& Napper, D. H. (1966). The cariostatic effect of carbohydrate phosphates in the diet. Australian Dental Journal 11, 388-395.

Lindhe, J. (1989). Textbook of Clinical Periodontology, 2nd edn. Copenhagen: Munksgaard.

Lindqvist, L. W. \& Carlsson, G. E. (1985). Long-term effects of chewing with mandibular fixed prostheses on osseointegrated implants. Acta Odontologica Scandinavica 43, 39-45.

Ludwig, T. G. \& Bibby, B. G. (1957). Acid production from different carbohydrate foods in plaque and saliva. Journal of Dental Research 36, 56-60.

McClure, F. J. \& Ruzicka, S. J. (1946). The destructive effect of citrate vs. lactate ions on rats' molar tooth surfaces, in vivo. Journal of Dental Research 25, 1-12.

MacDonald, S. P., Cowell, C. R. \& Sheiham, A. (1981). Methods of preventing dental caries used by dentists for their own children. British Dental Journal 151, 118-121.

MacGregor, A. B. (1963). Increasing caries incidence and changing diet in Ghana. International Dental Journal 13, 516-522.

McKay, F. S. (1916). An investigation of mottled teeth (I). Dental Cosmos 58, 477-484.

Magrill, D. S. (1973). The reduction of the solubility of hydroxyapatite in acid by adsorption of phytate from solution. Archives of Oral Biology 18, 591-600.

Mäkila, E. (1968). Effects of complete dentures on the dietary habits and serum thiamine, riboflavin and ascorbic acid levels in edentulous persons. Suomen Hammasläääriseuran Toimituksia 64, 107-152.

Mäkila, E. (1969a). Protein consumption and intake of essential amino acids, niacin and calcium before and after wearing complete dentures. Suomen Hammaslääkäriseuran Toimituksia 65, 125-133.

Mäkila, E. $(1969 b)$. Effects of complete dentures on dietary intake and serum levels of pantothenic acid, folic acid and iron in edentulous persons. Suomen Hammaslääkäriseuran Toimituksia 65, $299-311$.

Mansbridge, J. N. (1960). The effects of oral hygiene and sweet consumption on the prevalence of dental caries. British Dental Journal 109, 343-348.

Marshall-Day, C. D. (1944). Nutritional deficiencies and dental caries in Northern India. British Dental Journal 76, 115-122; 143-147.

Marthaler, T. M. (1967). Epidemiological and clinical dental findings in relation to intake of carbohydrates. Caries Research 1, 222-238.

Marthaler, T. M. (1979). Sugar and oral health: epidemiology in humans. In Health and Sugar Substitutes pp. 27-34 [B. Guggenheim, editor]. Basel: Karger.

Martinson, T. (1972). Socio-economic investigation of school-children with high and low caries frequency. III. A dietary study based on information given by the children. Odontologisk Revy 23, 93-114.

Mason, G. M., Chapple, I. L. C. \& Matthews, J. B. (1995). Local and systemic antioxidant capacity in chronic adult periodontal disease. Journal of Dental Research (in press).

Meehan, K., Touger-Decker, K. \& Vogel, R. (1995). Effect of edentulism and dentures on diet and nutritional status. Journal of Dental Research 74, Suppl. 79 pp.

Mellanby, M. (1918). An experimental study of the influence of diet on teeth formation. Lancet ii, 767-770.

Mellanby, M. \& Coumoulos, H. (1944). The improved dentition of 5-year-old London school-children. A comparison between 1943 and 1929. British Medical Journal i, 837-840.

Mellanby, M. \& Pattison, C. L. (1928). The action of vitamin D in preventing the spread and promoting the arrest of caries in children. British Medical Journal ii, 1079-1082.

Menaker, L. \& Navia, J. M. (1973). Effect of under-nutrition during the perinatal period on caries development in the rat. II. Caries susceptibility in underfed rats supplemented with protein or caloric additions during the suckling period. Journal of Dental Research 52, 680-687.

Menghini, G. D., Steiner, M., Marthaler, T. \& Bandi, A. (1995). [Incidence of caries in schoolchildren in the Glarus Canton in 1974-1992: effect of salt fluoridation.] Schweizerische Monatsschrift für Zahnmedizin 105, 467-473.

Meurman, J. H., Rytömaa, I., Kari, K., Laakso, T. \& Murtomaa, H. (1987). Salivary pH and glucose after consuming various beverages, including sugar-containing drinks. Caries Research 21, 353-359.

Mikx, F. H. M., van der Hoeven, J. S., Plasschaert, A. J. M. \& König, K. G. (1975). Effect of Actinomyces viscosius on the establishment and symbiosis of Streptococcus mutans and Streptococcus sanguis in SPF rats on different sucrose diets. Caries Research 9, 1-20.

Miller, W. D. (1907). Experiments and observations on the wasting of tooth tissue variously designated as erosion, abrasion etc. Dental Cosmos 49, 225-247. 
Millward, A., Shaw, L., Smith, A. J., Rippin, J. W. \& Harrington, E. (1994). The distribution and severity of tooth wear and the relationship between erosion and dietary constituents in a group of children. International Journal of Paediatric Dentistry 4, 151-157.

Moller, I. J. (1965). Dental Fluorose og Caries. Copenhagen: Rhodes International Science Publishers.

Mörch, T. (1961). The acid potentiality of carbohydrates; an investigation on some common dietary components in Norway. Acta Odontologica Scandinavica 19, 355-385.

Moynihan, P. J., Gould, M. E. L., Huntley, N. \& Thorman, S. (1995a). Effect of glucose polymers in water, milk and Calogen on plaque pH in vitro. International Journal of Paediatric Dentistry (in press).

Moynihan, P. J., Snow, S., Jepson, N. J. A. \& Butler, T. J. (1994). Intake of non-starch polysaccharide (dietary fibre) in edentulous and dentate persons: an observational study. British Dental Journal 177, $243-247$.

Moynihan, P. J., Walton, A. G. \& Wright, W. G. (1995b). A comparison of the relative acidogenic potential of standard infant milk formula and soya infant formula: a plaque pH study. International Journal of Paediatric Dentistry (in press).

Murray, J. J., Rugg-Gunn, A. J. \& Jenkins, G. N. (1991). Fluorides in Caries Prevention, 3rd edn. Oxford: Butterworth-Heinemann.

Nerf, D. (1967). Acid production from different carbohydrate sources in human plaque in situ. Caries Research $1,78-87$.

Newbrun, E. (1984). Diet and dental caries. In Cariology Today, pp. 340-352 [B. Guggenheim, editor]. Basel: Karger.

Newbrun, E. (1989). Cariology, 3rd edn. Chicago, IL: Quintessence.

Newbrun, E. (1990). The potential role of alternative sweeteners in caries prevention. Israel Journal of Dental Science 2, 328-345.

Newbrun, E., Hoover, C., Mettraux, G. \& Graf, H. (1980). Comparison of dietary habits and dental health of subjects with hereditary fructose intolerance and control subjects. Journal of the American Dental Association 101, 619-626.

Nikiforuk, G. \& Fraser, D. (1981). The etiology of enamel hypoplasia - a unifying concept. Journal of Pediatrics 98, 888-893.

Nizel, A. E. \& Harris, R. S. (1964). The effects of phosphates on experimental dental caries: a literature review. Journal of Dental Research 43, $1123-1136$.

O'Brien, M. (1994). Children's Dental Health in the United Kingdom 1993. Office of Population Censuses and Surveys, Social Survey Division. London: HMSO.

Office of Population Censuses \& Surveys (1995). National Diet and Nutrition Survey: Children Aged $1 \frac{1}{2}$ lo $4 \frac{1}{2}$ Years, vol. 2: Report of the Dental Survey, pp. 35, 36. London: HMSO.

Oliver, W. M. (1969). The effect of deficiencies of calcium, vitamin D or calcium and vitamin D and variations in the source of dietary protein on the supporting tissues of the rat molar. Journal of Periodontal Research 4, 56-69.

Olojugba, O. O. \& Lennon, M. A. (1987). Dental caries experience in 5- and 12-year-old schoolchildren in Ondo State, Nigeria in 1977 and 1983. Community Dental Health 4, 129-135.

Olojugba, O. O. \& Lennon, M. A. (1990). Sugar consumption in 5- and 12-year-old schoolchildren in Ondo State, Nigeria in 1985. Community Dental Health 7, 259-265.

Olsson, B. (1978). Dental caries and fluorosis in Arussi province, Ethiopia. Community Dentistry and Oral Epidemiology 6, 338-343.

Olsson, B. (1979). Dental health situation in privileged children in Addis Ababa, Ethiopia. Community Dentistry and Oral Epidemiology 7, 37-41.

O'Rourke, J. T. (1947). The relationship of the physical character of the diet to the health of the periodontal tissues. American Journal of Orthodontics and Oral Surgery 33, 687-700.

Osterberg, T. \& Steen, B. (1982). Relationship between dental state and dietary intake in 70-year-old males and females in Goteberg, Sweden: a population study. Journal of Oral Rehabilitation 9, 509-521.

Pack, A. R. C. (1984). Folate mouthwash; effects on established gingivitis in periodontal patients. Journal of Clinical Periodontology 11, 619-628.

Pack, A. R. C. \& Thompson, M. E. (1980). Effects of topical and systemic folic acid supplementation on gingivitis in pregnancy. Journal of Clinical Periodontology 7, 402-414.

Parfitt, G. J. \& Hand, C. D. (1963). Reduced plasma ascorbic acid levels and gingival health. Journal of Periodontology 34, 347-351.

Pearce, E. I. F. \& Bibby, B. G. (1966). Protein adsorption on bovine enamel. Archives of Oral Biology 11, $329-336$.

Perlitsh, M. J., Neilsen, A. G. \& Stanmyer, W. R. (1961). Ascorbic acid plasma levels and gingival health in personnel wintering over in Antarctica. Journal of Dental Research 40, 789-799.

Persson, L.-A., Stecksen-Blick, C. \& Holm, A.-K. (1984). Nutrition and health in childhood, causal and quantitative interpretations of dental caries. Community Dentistry and Oral Epidemiology 12, 390-397.

Pickerill, H. P. (1912). Prevention of Dental Caries and Oral Sepsis, p. 140. London: Baillière, Tíndall and Cox.

Pindborg, J. J. (1949). The effect of methyl folic acid on the periodontal tissue in rat molars (experimental granulocytopenia). Oral Surgery, Oral Medicine and Oral Pathology 2, 1485-1496.

Poulsen, S., Larsen, M. J. \& Larsen, R. H. (1976). Effect of fluoridated milk and water on enamel fluoride content and dental caries in the rat. Caries Research 10, 227-233. 
Rankine, C. A. N., Prihoda, T. J., Etzel, K. R. \& Labadie, D. (1989). Plaque fluid pH, calcium and phosphorus responses to calcium food additives in a chewable candy. Archives of Oral Biology 34, 821-824.

Rateitschak-Pluss, E. M. \& Guggenheim, B. (1982). Effects of a carbohydrate free diet and sugar substitutes on dental plaque accumulation. Journal of Clinical Periodontology 9, 239-251.

Reuter, J. E. (1978). Unusual dental incisal erosion. British Dental Journal 145, 274

Reynolds, E. C. (1987). The prevalence of subsurface demineralization of bovine enamel and change in plaque composition by casein in an intra-oral model. Journal of Dental Research 66, 1120-1127.

Reynolds, E. C. \& Black, C. L. (1987). Reduction of chocolate's cariogenicity by supplementation with sodium caseinate. Caries Research 21, 445-451.

Reynolds, E. C. \& Black, C. L. (1989). Cariogenicity of a confection supplemented with sodium caseinate at a palatable level. Caries Research 23, 368-370.

Reynolds, E. C. \& Johnson, I. H. (1981). Effect of milk on caries incidence and bacterial composition of dental plaque in the rat. Archives of Oral Biology 26, $445-451$.

Richardson, A. S., Hole, L. W., McCombie, F. \& Kolthammer, J. (1972). Anticariogenic effect of di-calcium phosphate dihydrate chewing gum. Journal of the Canadian Dental Association 38, 213-218.

Rugarabaum, P., Frencken, J. E., Amuli, J. A. D. \& Lihepa, A. (1990). Caries experience amongst 12- and 15year-old Tanzanian children residing on a sugar estate. Community Dental Health 7, 53-58.

Rugg-Gunn, A. J. (1993). Nutrition and Dental Health. Oxford: Oxford Medical Publications.

Rugg-Gunn, A. J., Edgar, W. M., Geddes, D. A. M. \& Jenkins, G. N. (1975). The effect of different meal patterns upon plaque pH in human subjects. British Dental Journal 139, 351-356.

Rugg-Gunn, A. J., Edgar, W. M. \& Jenkins, G. N. (1978). The effect of eating some British snacks upon the pH of human dental plaque. British Dental Journal 145, 95-100.

Rugg-Gunn, A. J., Edgar, W. M., Jenkins, G. N. \& Cockburn, M. A. (1976). Plaque F and plaque acid production in children drinking milk fluoridated to 1 and 5 p.p.m. Journal of Dental Research 55, D143 (Abstr.)

Rugg-Gunn, A. J., Hackett, A. F. \& Appleton, D. R. (1987). Relative cariogenicity of starch and sugars in a two year longitudinal study of 405 English school-children. Caries Research 21, 464-473.

Rugg-Gunn, A. J., Hackett, A. F., Appleton, D. R., Jenkins, G. N. \& Eastoe, J. E. (1984). Relationship between dietary habits and caries increment assessed over two years in 405 English adolescent schoolchildren. Archives of Oral Biology 29, 983-992.

Rugg-Gunn, A. J., Roberts, G. J. \& Wright, W. G. (1985). The effect of human milk on plaque pH in situ and enamel dissolution in vitro compared with bovine milk, lactose and sucrose. Caries Research 19, $327-334$.

Rusoff, L. L., Konikoff, B. S., Frye, J. B., Johnston, J. E. \& Frye, W. W. (1962). Fluoride addition to milk and its effect on dental caries in school children. American Journal of Clinical Nutrition 11, 94-101.

Russell, A. L. (1963). International nutrition surveys: a summary of preliminary dental findings. Journal of Dental Research 42, 233-244.

Russell, A. L., Littleton, N. W., Leatherwood, E. C., Sydow, G. E. \& Greene, J. C. (1960). Dental surveys in relation to nutrition. Public Health Reports 75, 717-723.

Russell, R. R. B., Aduse-Opoku, J., Sutcliffe, I. C., Tao, L. \& Ferretti, J. J. (1992). A binding protein-dependent transport system in Streptococcus mutans responsible for multiple sugar metabolism. Journal of Biological Chemistry 267, 4631-4637.

Sandstrom, B. \& Lindqvist, L. W. (1987). The effect of different prosthetic restorations on the dietary selection of edentulous patients. Acta Odontologica Scandinavica 45, 423-428.

Sarnat, H., Eliaz, R., Feiman, G., Flexer, Z., Karp, M. \& Laron, Z. (1985). Carbohydrate consumption and oral status of diabetic and non-diabetic young adolescents. Clinical and Preventive Dentistry 7, $20-23$.

Sato, Y., Minagi, S., A kagawa, Y. \& Nagasawa, T. (1989). An evaluation of chewing function of complete denture wearers. Journal of Prosthetic Dentistry 62, 50-53.

Schamschula, R. G., Adkins, B. L., Barmes, D. E., Charlton, G. \& Davey, B. G. (1978). WHO Study of Dental Caries Etiology in Papua New Guinea. WHO Publication no. 40.

Scheinin, A. (1979). Influence of the diagnostic level on caries incidence in two controlled clinical trials. Caries Research 13, 91 (Abstr. 20).

Scheinin, A. \& Mäkinen, K. K. (1975). Turku sugar studies. I-XXI. Acta Odontologica Scandinavica 33, Suppl. $70,1-139$.

Schemmel, R. A., Krohn-Lutz, K., Lynch, P. \& Kabara, J. J. (1982). Influence of dietary disaccharides on mouth microorganisms and experimental dental caries in rats. Archives of Oral Biology 27, 435-441.

Schmid, R., Cleaton-Jones, P. \& Lutz, F. (1987). Cariogenicity of uncooked and cooked traditional African foodstuffs in rats. Caries Research 21, 339-345.

s'Gravenmade, E. J. \& Jenkins, G. N. (1986). Isolation, purification and some properties of a potential cariostatic factor in cocoa that lowers enamel solubility. Caries Research 20, 433-436.

Shannon, I. L. \& Gibson, W. A. (1965). Intravenous ascorbic acid loading in subjects classified as to periodontal status. Journal of Dental Research 44, 355-361.

Shaw, J. H. (1962). The relation of nutrition to periodontal disease. Journal of Dental Research 41, (Suppl.) 264-274.

Shaw, J. H. (1979). Changing food habits and our need for evaluation of the cariogenic potential of foods and confections. Pediatric Dentistry 1, 192-198. 
Shaw, J. H. (1980). Influences of sodium, calcium and magnesium trimetaphosphates on dental caries activity in the rat. Journal of Dental Research 59, 644-650.

Shaw, J. H. (1983). Sugar and caries. 6. Evidence from experimental animal research. Journal of Dentistry 11 , 209-213.

Shaw, J. H., Ensfield, B. J. \& Wollman, D. H. (1959). Studies on the relation of dairy products to dental caries in caries-susceptible rats. Journal of Nutrition 67, 253-273.

Sidi, A. D. \& Ashley, F. P. (1984). Influence of frequent sugar intakes on experimental gingivitis. Journal of Periodontology 55, 419-423.

Silva, M. F. de A., Jenkins, G. N., Burgess, R. C. \& Sandham, H. J. (1986). Effects of cheese on experimental caries in human subjects. Caries Research 20, $263-269$.

Silverstein, S. J., Knapp, J. F., Kircos, L. \& Edwards, H. (1983). Dental caries prevalence in children with a diet free of refined sugar. American Journal of Public Health 73, 1196-1199.

Slade, E. W., Bartuska, D., Rose, L. F. \& Cohen, D. W. (1976). Vitamin E and periodontal disease. Journal of Periodontology 47, 352-354.

Smith, A. J. \& Shaw, L. (1987). Baby fruit juices and tooth erosion. British Dental Journal 162, $65-67$.

Sognnaes, R. F. (1948). Analysis of wartime reduction of dental caries in European children, with special reference to observations in Norway. American Journal of Diseases of Childhood 75, 792-821.

Sperling, G., Lovelace, F., Barnes, L. L., Smith, C. A. H., Saxton, J. A. \& McCay, C. M. (1955). Effect of long time feeding of whole milk diets to white rats. Journal of Nutrition 55, 399-414.

Sreebny, L. M. (1982). The sugar-caries axis. International Dental Journal 32, 1-12.

Sreebny, L. M. (1983). Cereal availability and dental caries. Community Dentistry and Oral Epidemiology 11 , 148-155.

Stephan, R. M. (1940). Changes in hydrogen ion concentration on tooth surfaces and in carious lesions. Journal of the American Dental Association 27, 718-723.

Stephen, K. W., Boyle, I. T., Campbell, D., McNee, S. \& Boyle, P. (1984). Five-year double-blind fluoridated milk study in Scotland. Community Dentistry and Oral Epidemiology 12, 223-229.

Stephen, K. W., Boyle, I. T., Campbell, D., McNee, S., Fyffe, J. A., Jenkins, A. S. \& Boyle, P. (1981). A 4-year double-blind fluoridated school milk study in a vitamin-D deficient area. British Dental Journal 151, $287-292$.

Sterkey, G., Kjellman, O., Högberg, O. \& Löfroth, A.-L. (1971). Dietary composition and dental disease in adolescent diabetics. Acta Paediatrica Scandinavica 60, 461-464.

Stralfors, A. (1966). Inhibition of hamster caries by cocoa. Archives of Oral Biology 11, 232-238.

Sundin, B., Birkhed, D. \& Granath, L. (1983). Is there not a strong relationship nowadays between caries and consumption of sweets? Swedish Dental Journal 7, 103-108.

Sweeney, E. A., Saffir, A. J. \& de Leon, R. (1971). Linear hypoplasia of deciduous incisor teeth in malnourished children. American Journal of Clinical Nutrition 24, 29-31.

Takahashi, K. (1961). Statistical study on caries incidence in the first molar in relation to the amount of sugar consumption. Bulletin of the Tokyo Dental College 2, 44-57.

Tank, G. \& Storvick, C. A. (1965). Caries experience of children one- to six-years old in two Oregon communities (Corvallis and Albany). Ill. Relation of diet to variation of dental caries. Journal of the American Dental Association 70, 394-403.

Tanzer, J. M. \& Slee, A. M. (1983). Saccharin inhibits tooth decay in laboratory models. Journal of the American Dental Association 106, 331-333.

Tavares, M., De Paola, P., Soparkar, P. \& Joshipura, K. (1991). The prevalence of root caries in a diabetic population. Journal of Dental Research 70, 979-983.

Tehrani, A., Brudevold, F., Attarzadeh, F., van Houte, J. \& Russo, J. (1983). Enamel demineralization by mouthrinses containing different concentrations of sucrose. Journal of Dental Research 62, 1216-1217.

Thompson, M. E., Dever, J. G. \& Pearce, E. I. F. (1984). Intra-oral testing of flavoured sweetened milk. New Zealand Dental Journal 80, 44-46.

Tomlinson, T. H. (1939). Oral pathology in monkeys in various experimental dietary deficiencies. Public Health Reports 54, 431-439.

Toth, K. (1976). A study of 8 years domestic salt fluoridation for prevention of caries. Community Dentistry and Oral Epidemiology 4, 106-110.

van Herpen, B. P. J. M. \& Arends, J. (1986). Influence of the composition frequency of filled chocolate products on the demineralization of human enamel in vivo. A microhardness and microradiographic investigation. Caries Research 20, 529-533.

van Houte, J. \& Duchin, S. (1975). Streptococcus mutans in the mouths of children with congenital sucrase deficiency. Archives of Oral Biology 20, 771-773.

Villa, A., Guerrero, S., Cisternas, P. \& Monckeberg, F. (1989). Fluoride bio-availability from disodium monofluorophosphate fluoridated milk in children and rats. Caries Research 23, 179-183.

Vogel, R. I. (1977). Gingival hyperplasia and folic acid deficiency from anti-convulsive drug therapy: a theoretical relationship. Journal of Theoretical Biology 67, 269-278.

Vogel, R. I. \& Deasy, M. (1978). The effect of folic acid on experimentally produced gingivitis. Journal of Preventive Dentistry 5, 30-32.

Vogel, R. I., Fink, R., Frank, O. \& Baker, H. (1978). The effect of topical applications of folic acid on gingival health. Journal of Oral Medicine 33, 20-22. 
Waerhaug, J. (1967). Prevalence of periodontal disease in Ceylon. Acta Odontologica Scandinavica 25, 205-231. Walls, A. W. G. \& Donachie, M. A. (1995). The dental status of a sample of the aging population in Newcastle upon Tyne, England. British Dental Journal (in press).

Weiss, S. J. (1989). Tissue destruction by neutrophils. New England Journal of Medicine 320, 365-376.

Wespi-Eggenberger, H. J. (1948). [Observations on optimum nutrition in pregnancy. Salt and bread as vehicles of dietary supplements.] Schweizerische Medizinische Wochenschrift 78, 153-155.

Whiting, G. C., Sutcliffe, I. C. \& Russell, R. R. B. (1993). Metabolism of polysaccharides by the Streptococcus mutans dexB gene product. Journal of General Microbiology 139, 2019-2026.

WHO/FDI (1985). Report of a Working Group convened jointly by the FDI and the WHO: changing patterns of oral health and implications for oral health manpower, part 1. International Dental Journal 35, 235-251.

Woodward, M. \& Walker, A. R. P. (1994). Sugar consumption and dental caries: evidence from 90 countries. British Dental Journal 176, 297-302.

Zahlaka, M., Mitri, O., Munder, H., Mann, J., Kaldavi, A., Galon, H. \& Gedalia, I. (1987). The effect of fluoridated milk on caries in Arab children: results after 3 years. Clinical and Preventive Dentistry 9, 23-25.

Ziegler, E. (1962). Milk fluoridation. Bulletin der Schweizerischen Akademie der Medizinischen Wissenschaften 18, 379-391. 